\title{
Narrando viagens e invenções. Hercule Florence: amigo das artes na periferia do capitalismo
}

\section{Dirceu Franco Ferreira ${ }^{1}$}

RESUMO: $\bigcirc$ volumoso manuscrito de 423 páginas redigido entre 1837 e 1859, por Antoine Hercule Romuald Florence (1804-1879), intitulado L'ami des arts livré à lui-même. Recherche et découvertes sur différents sujets nouveaux, traz uma compilação dos principais objetos de estudo e reflexão desse franco-monegasco radicado no Brasil. Neste artigo, o L'ami des arts é compreendido como ponto de partida para uma contextualização das pesquisas que resultaram na invenção da photographie, método de reprodução de textos e desenhos anunciado na Província de São Paulo em 1834. Em seguida, a leitura do relato da Expedição Langsdorff apresentado no mesmo manuscrito foi, por sua vez, o ponto de partida para estabelecer uma classificação das diferentes versões escritas por Florence. A partir da pesquisa em suas correspondências ativas foi ainda possível recuperar o esforço do autor para publicar a conhecida narrativa de Viagem Fluvial. De modo geral, busca-se, aqui, problematizar a cronologia de suas invenções e das versões de seu relato da expedição Langsdorff, mostrando as intersecções entre as narrativas das invenções e das viagens, em especial o cruzamento fixado na matriz autobiográfica.

PALAVRAS-CHAVE: Hercule Florence. Artes gráficas. Poligrafia. Fotografia. Expedição Langsdorff. Século XIX.

ABSTRACT: The voluminous manuscript of 423 pages written between 1837 and 1859, by Antoine Hercule Romuald Florence (1804-1879), entitled L'ami des arts Livré à lui-même. Recherche et Découvertes sur différents sujets nouveaux, is a compilation of the main objects of study and reflection of this Franco-Monegasque settled in Brazil. In this article, L'ami des arts is understood as a starting point for a contextualization of the research that resulted in the invention of photographie by Florence, method of reproduction of texts and drawings announced in the Province of São Paulo in 1834. Then we read the report of the Langsdorff Expedition presented in the same manuscript as the starting point to establish a classification of other different versions written between 1828 e 1875 . From the research into his active correspondence was still possible to recover the author's efforts to publish the well known narrative of the Voyage. In general, this
1. Pós-graduando na FFLCH-USP. E-mail: <dirceu.ferreira@usp.br> 
2. A pesquisa que endossou este artigo contou com o apoio do Instituto Hercule Florence, em São Paulo, em cujo acervo encontram-se conservados os manuscritos de Hercule Florence. O autor agradece o apoio e auxílio prestados por Antonio Florence e Francis Melvin Lee.

3. Ver Pietro Maria Bardi (1979).

4 Charles Auguste Taunay (1791-1867), ou Major Taunay, era filho de Nicolas Antoine Taunay, portanto, irmão de Aimée-Adrien Taunay e Félix Taunay. Florence teve relação estreita com a família Taunay ao longo de toda sua vida. Como demonstrado no texto, Adrien, Charles, Félix e, o filho deste, Alfredo cumpriram papéis decisivos na obra iconográfica, científica e histórica de Florence.

5. "Nous entreprendrons la publication de la vie d'un inventeur et artiste abandonné à lui-même pendant 32 ans dans l'intérieur du Brésil. Il n'y entre aucune fiction, ce sera la pure réalité; et en cela ce tableau sera réel et non supposé comme Robinson, ou l'Oncle Tom et tous les romans. Nous aurons la propriété en commun, et nous partagerons les pertes et bénéfices s'il y en a. Donnez à cette publication le titre que vous voudrez; je m'incline à celui d' "Oncle Tom de race blanche"; mais pour le moment conservons lui celui d' 'Inventeur au Brésil'”. Correspondência de Hercule Florence a Charles Taunay, À Monsieur Charles Auguste Taunay, Major au service du Brésil. Rio-de-Janeiro Septembre 1862. L'inventeur au Brésil. Correspondances et pièces scientifiques. Coleção Arnaldo Machado Florence, Instituto Hercule Florence, São Paulo. article raises questions about the chronology of his inventions and his narrative versions of the Langsdorff expedition, showing the intersections between narrative inventions and the experience of the voyage in nineteenth century, enlightening the crossing set in autobiographical matrix. KEYWORDS: Hercule Florence. Print Arts. Polygraphy. Photography. Langsdorff Expedition. 19th Century.

L'ami des arts livré à lui-même. Recherche et découvertes sur différents sujets nouveaux, volumoso manuscrito de 423 páginas $^{2}$, redigido entre 1837 e 1859 por Antoine Hercule Romuald Florence (1804-1879), viajante e inventor franco-monegasco radicado no Brasil, contém três obras em uma: científica, pois apresenta as principais invenções às quais se dedicou o poliédrico ${ }^{3}$ pai da fotografia; autobiográfica, na medida em que narra os primeiros arroubos da infância e juventude do autor, das bordas do Mediterrâneo até sua chegada ao Rio de Janeiro em 1824; e histórico-filosófica, porque traz uma narrativa da Expedição Langsdorff (1825-1829) que, nos moldes da literatura de viagem da primeira metade do oitocentos, faz dialogar elementos da realidade local com teorias sociais em gestação na Europa.

Em carta ao major Charles Taunay ${ }^{4}$, de setembro de 1862, Florence fez referência à edição de seu manuscrito como uma obra realista, sem suposições nem ficção:

Empreenderemos a publicação da vida de um inventor e artista abandonado à própria sorte por 32 anos no interior do Brasil. Não entrará nenhuma ficção, será a pura realidade; e nela o quadro será real e não suposto como em Robinson, Pai Tomás e todos os outros romances. Dividiremos a propriedade da obra e compartilharemos as perdas e os ganhos, se houver. Dê a essa publicação o título que desejar; estou inclinado a aceitar este de "Pai Tomás da raça branca"; mas, por enquanto, conservemos o de "Inventor no Brasil"5.

Robinson, Oncle Tom de race blanche ou inventeur en exil são metáforas poéticas frequentemente empregadas por Florence. Elas revelam o esforço do autor em divulgar suas invenções e a experiência do deslocamento vivida por esse humanista nos trópicos ${ }^{6}$. Como um mestre trabalhando na periferia do capitalismo 7 , Florence encontrou as mesmas dificuldades que artistas, romancistas, fotógrafos, impressores e poetas enfrentavam para divulgar sua arte e, ao mesmo tempo, extrair dela sua subsistência. Numa época em que a formação superior era dominada pelo bacharelismo e as artes prosperavam com a subvenção do poder imperial, ele colheu poucos frutos de seus inventos. Soube, no entanto, compreender e fazer suas escolhas diante das dificuldades do meio.

No que são melhores do que eu todos esses felizes inventores que possuem tudo a seu alcance nas cidades da Europa, artistas, sábios, materiais e etc., aplausos, recompensas, ou mesmo a glória, enquanto que aqui eu não consigo sequer encontrar um operário capaz de me fazer uma régua de metal de vinte centímetros bem reta? 
Eu deveria, segundo dizem alguns, renunciar a tudo e me ocupar apenas do que é apreciado nesta região, ou seja, ganhar dinheiro? Mas então, sob este novo despotismo, não haveria mais vocação, sacerdócio, e nossa sociedade, recusando o progresso moral, poderia cair na condição das abelhas que hoje trabalham como há 6000 anos $^{8}$.

Redigido quase integralmente em francês, L'ami des arts livré à lui-même nunca foi publicado na forma como seu autor o idealizara9. A sua edição reunindo o conteúdo original do manuscrito, sua transcrição e a tradução para o português - cobriria importante lacuna na literatura produzida em torno da vida e da obra de Florence. Ao longo dos anos, alguns desenhos e textos foram desmembrados do caderno original, mas ainda é possível reconstituir quase todo o seu conteúdo por meio de reproduções existentes no Acervo do Instituto Hercule Florence ou mesmo de originais da coleção Cyrillo Hercules Florence, ambos localizados em São Paulo. Neste artigo, além de uma breve exposição do conteúdo do L'ami des arts, pretende-se contextualizar a obra de Florence, problematizando a cronologia de suas invenções e das versões da sua narrativa da expedição Langsdorff.

Apesar do conteúdo apresentado nos manuscritos reunidos no L'ami des arts ser formalmente dividido em capítulos, é possível discernir, no conjunto, duas partes distintas. Na primeira, Florence reúne os registros relativos às suas principais invenções: poligrafia, fotografia (impressão pela luz solar), papel-inimitável, noriahidrostática, estudo dos céus para jovens paisagistas, zoofonia (pesquisa sobre a voz dos animais), quadros-transparentes (dos quais derivaram nos anos 1860 os estudos da estereopintura), um estudo sobre a compressão do gás hidrogênio para uso nos voos de aerostáticos, um ensaio sobre a impressão de pinturas a óleo em estampas, a fabricação de chapéus de palha e o uso de tipos-sílabas na impressão tipográfica.

A segunda parte é dedicada à autobiografia e à narrativa da Expedição Langsdorff. Nela, o autor narra sua história de vida, do nascimento aos vinte anos de idade, privilegiando aspectos da infância e da juventude entre Nice, Vintimille e Mônaco e as primeiras manifestações de seu espírito aventureiro, a motivação que o lançaria ao mar. Florence descreve sua primeira viagem a pé, percorrendo as principais cidades da porção oeste da Europa, desde a Antuérpia até Mônaco, passando por Bruxelas, Paris, Aix-en-Provence e Brignole. Em seguida, relata o drama de sua mãe ao saber que continuaria viajando, agora para o além-mar. Por fim, dedica mais de 200 páginas à narrativa de sua participação na conturbada expedição que o Barão de Langsdorff, financiado pelo Império Russo, dirigiu entre 1825 e 1829. Contratado como geógrafo e segundo desenhista da expedição, Florence fez uma descrição pormenorizada do trajeto fluvial percorrido pelos viajantes ao longo das províncias de São Paulo, Mato Grosso e Grão-Pará, gravando seu nome na história dos relatos de viagem como autor de uma das narrativas da segunda parte da expedição, reputa-se a mais completa.
6. Ver Dirceu Ferreira e Nelson Cantarino (2009).

7. Ver Roberto Schwarz (2000).

8. "Qu'ont-ils de mieux que moi tous ces inventeurs heureux qui ont tout à leur portée dans les Villes d'Europe, artistes, savants, matériaux etc.[,] a p plaudis sements, récompenses, ou enfin la gloire, tandis qu'ici je n'ai pas même rencontré un ouvrier capable de me faire une règle de métal de deux décimètres bien droite? Devrais-je selon le dire de quelques-uns, renoncer à tout cela, et ne m'occuper que de ce qui est apprécié dans le pays, c'est-à-dire, gagner de l'argent? Mais alors sous ce nouveau despotisme il n'y aurait plus de vocation, plus de sacerdoce, et nos sociétés en bannissant le progrès moral pourraient tomber dans la condition des abeilles qui travaillent aujourd'hui comme il y a 6000 ans ". Correspondência de Hercule Florence a Charles Taunay, L'inventeur au Brésil...

9. Apesar do caderno L'ami des arts não ter sido publicado integralmente, dele saíram publicações parciais. Todas dedicadas à divulgação da narrativa da expedição Langsdorff, concentrada entre as páginas 197 e 423 do caderno. São elas: Florence, (1904, 1905, 1906, 1 a 7, 9 a 12, 1907, 1912, 1977).

10. Bonapartista exilado da França restaurada pela casa de Bourbon, Pierre René François Plancher de la Noé estabeleceu sua tipografia no Rio de Janeiro em meio às agitações d a independência política do Brasil, em 1822. Tornou-se impressor Real em 15 de maio de 1824, imprimiu a Constituição do Império, fundou os jornais Spectador Brasileiro e Jornal do 
Commercio, além de ter impresso autores clássicos da política e algumas obras de ficção. A passagem de Florence pela oficina tipográfica de Pierre Plancher foi marcante para sua formação nas artes gráficas e também na sua iniciação política. Laurence Hallewell, em seu O livro no Brasil, aponta que Plancher trouxera na bagagem autores do Iluminismo francês, "entre eles, d'Alembert, Biot, Briant, Broussais, Carnet, Condillac, Constant, Diderot, Dumas, Dupuis, Miguet, Mirabeau, Montesquieu, Parisset e Poiret", cf. Laurence Hallewell (2005 p. 68). homem de invenções e as artes gráficas

A trajetória de Hercule Florence foi diferente da de boa parte dos viajantes aportados no Brasil na primeira metade do século XIX. Não viajou com patrocínio de monarquia ou academia de ciência, muito menos despendeu fortuna própria. Nascido na cidade de Nice, sul da França, era filho de Arnaud Florence, cirurgião do exército de Napoleão, e Augustine de Vygnallis, camponesa natural de Mônaco. Órfão de pai aos três anos, Florence foi criado junto à família de sua mãe, entre artesãos, mestres de ofício e pintores, muitos deles educados nas escolas de arte de Roma e Paris. Sabe-se, pela autobiografia manuscrita no L'ami des arts, que, até seus vinte anos, estudou desenho, obteve noções de cartografia, teve acesso à literatura de viagem e, principalmente, alimentou o desejo pela descoberta do Novo Mundo de modo muito particular, qual seja, o da aventura. Guiado por esse espírito aventureiro e, aceito como grumete pelo capitão Du Campe de Rosamel, Florence desembarcou no Rio de Janeiro em 1824.

Trabalhou por dois anos no Rio de Janeiro, com o comerciante Pierre Dillon e com o tipógrafo e editor Pierre Plancher ${ }^{10}$. Percorreu, por via fluvial, como geógrafo e segundo desenhista da expedição científica dirigida pelo Barão de Langsdorff, as províncias de São Paulo, Mato Grosso e Grão-Pará, entre 1825 e 1829. Dedicou-se ao estudo da pintura na Academia de Belas Artes do Rio de Janeiro, sob a orientação de Félix Émile Taunay durante seis meses, em 1829. Estabeleceu-se na pacata e rural vila de São Carlos (hoje cidade de Campinas), onde se casou com Maria Angélica Álvares Machado e Vasconcellos em 4 de janeiro de 1830. Em 1837, ao iniciar a redação do L'ami des arts, Florence estava com 33 anos de idade, sendo treze já vividos no Brasil. Radicado no seio da família de Francisco Álvares Machado e Vasconcelos (1791-1846), Florence regressaria a Mônaco apenas em 1855, em visita aos parentes. Foi, portanto, na Província de São Paulo que ele desenvolveu os estudos e invenções descritos a seguir.

Da autografia à poligrafia

Uma das primeiras invenções de Florence, a autografia pode ser vista como parte de um processo identificado no conjunto de pesquisas que, desde o final do século XVIII, vinham sendo realizadas concomitantemente no Velho e no Novo Mundo a fim de aprimorar as técnicas de impressão e gravação de textos e imagens. Desde a invenção da litografia por Alois Senefelder, em 1798, até o anúncio do daguerreótipo, em 1839, cientistas, gravadores, viajantes e impressores lançaram-se na busca de técnicas que não só permitissem a reprodução fiel da natureza, mas também atendessem à crescente demanda por impressos, aquecida desde o advento do lluminismo na Europa. Ao lado da fotografia, essas novas técnicas de impressão e reprodução de imagens foram agentes decisivos na multiplicação e variação dos usos e funções da representação visual. Ivins Jr. sugere que o número de imagens impressas no século XIX foi maior que o dos três séculos 
precedentes $^{11}$. A informação visual, mercadoria inserida numa economia de escala transcontinental, foi aos poucos se transformando no paradigma de observação, representação e construção do real.

Observando as necessidades do meio em que se encontrava e insatisfeito com a edição de seu manuscrito Recherches sur la voix des animaux ${ }^{12}$, feita pelo tipógrafo R. Ogier em 1831, Florence lançou-se na pesquisa por técnicas de impressão, a um só tempo, baratas e precisas. Assim, diante das condições de trabalho que a realidade socioeconômica da ex-colônia portuguesa the oferecia ${ }^{13}$, Florence inventaria a autografia, um processo de reprodução bastante rudimentar. Os experimentos que resultaram na invenção da nova técnica foram realizados na Rua das Flores (atual José Paulino), 53, no Bom Retiro, bairro da capital paulista onde Florence morou entre 1830 e 1831 . Ali, se ocupava do ensino de pintura e da venda de retratos desenhados por ele, conforme revela um anúncio publicado no periódico liberal Farol Paulistano:

Hercule Florence, pintor retratista, morador da Rua das Flores casa $n^{\circ} 53$ annuncia que elle dará lições de desenho em sua casa, e para as Snras nas suas casas. - Tem também para vender, os retratos de alguns Srs. Deputados: a preço, \$2000 cada um. As vistas de Ytú e do Salto do mesmo, por preços cômodos ${ }^{14}$.

$\bigcirc$ primeiro manuscrito em que Florence expõe os recursos utilizados na autografia, com data estimada em 1830, intitula-se Ensaio sobre huma imprensa de algibeira ${ }^{15}$ (Figura 1). $\bigcirc$ texto descreve um aparelho leve, constituído basicamente por papel, tinta e canivete. Um instrumento simples a ser utilizado por qualquer indivíduo interessado em imprimir e divulgar textos, panfletos, anúncios ou libelos em qualquer lugar. A técnica fundia a simplicidade no fazer com a superação do obstáculo imposto pelas dificuldades de locomoção. $\bigcirc$ procedimento para multiplicar as matrizes por esse método consistia no seguinte:

1. Preparação do molde, ou folha matriz: as letras que se quer imprimir devem ser feitas numa folha de papel, por meio de pequenos cortes de canivete, de modo que se permita à tinta, num momento posterior, atravessar o papel apenas onde houver corte. Em seguida, aplica-se ao papel certa quantidade de óleo de linhaça, substância que terá efeito de verniz. Por fim, esse papel deve ser fixado numa moldura, para que permaneça rigidamente esticado.

2. Impressão: sobre uma mesa coloca-se uma folha limpa, na qual será impresso o desenho ou texto presente no molde ou folha matriz. Sobre a folha limpa, colocase a folha matriz de maneira que o desenho ou texto fique com a frente voltada para o autor da impressão. Coloca-se, então, a tinta sobre a folha matriz, evitando pressioná-la. Deve-se tomar cuidado ainda maior para que a moldura não se mexa durante o processo, evitando perda de trabalho. A tinta deverá, assim, atravessar os cortes feitos na folha matriz e impregnar a folha limpa. Dessa forma, após a secagem, poder-se-á visualizar o desenho ou o texto impresso.
11. "(...) they were made for all classes of society and for every conceivable purpose". Cf. William Ivins Jr. (1985, p. 93)

12. Este foi o primeiro manuscrito do estudo que Florence desenvolveu sobre a "voz dos animais". Entre os anos 1829-1830, Florence sistematizou algumas anotações realizadas durante a expedição Langsdorff com a finalidade de desenvolver um estudo acerca da voz dos animais. Publicado em 1831 pela Tipografia R. Ogier, no Rio de Janeiro, o estudo foi apresentado sob o título Mémoire sur la possibilité de décrire les sons et les articulations de la voix des animaux. Em outros manuscritos, o estudo dos sons e da voz dos animais receberia as denominações de "zoofonologia" e "zoofonia". O método da zoofonia consiste na representação gráfica dos sons emitidos pelos animais por meio de notas musicais. A despeito de suas limitações científicas, a zoofonia revela traços fundamentais do universo mental dominante na época em que foi produzida. Ao justificar a relevância de seu estudo, Florence insere-o no sistema das ciências naturais mais tradicionais das academias europeias: "Je dirai même qu'il offrirait quelque chose de plus agréable et de plus propre à exciter la curiosité, car la même manière que la Minéralogie est une étude de la Nature passive, la Zoologie une étude de la Nature active; ce serait une étude de la Nature parlante". Cf. Hercule Florence, (1993. p. 19).

13. Recomenda-se aqui a leitura do trabalho de Rosana Monteiro, (2001). A autora descreve com minúcia a relação de Florence com as condições de trabalho que o meio lhe oferecia e argumenta que as 
adversidades fizeram parte constitutiva de seu processo de invenção da fotografia.

14. O Farol Paulistano (08 jun. 1830, p. 4). Disponível em: http://memoria.bn.br/ DocReader/DocReaderaspx ?bib $=700169 \&$ PagFis $=1781$. Acesso em: 25 ago. 2012. $\mathrm{Na}$ edição de 11 de dezembro do mesmo jornal, Florence fez publicar um anúncio justificando ainda não ter atendido ao pedido de um grande número de pessoas "que lhe encomendaram o retrato do Martir da Liberdade o Doutor J. B. Badaró, por ter sido ocupado em fazer duas copias em ponto grande do mesmo retrato, os quais não podem sofrer demora, por ser um destinado à Sociedade Philantrópica e outro aos funerais que se preparam em S. Carlos". Cerca de vinte dias depois, já era possível adquirir o retrato de Badaró "na travessa de cima do quartel do $6^{\circ}$ Batalhão, casa n. ${ }^{\circ} 12$ ", por 800 réis.

15. Acervo Instituto Moreira Salles / Rio de Janeiro (a seguir: Acervo IMS/RJ), Código: 014Florence01C. O documento não está datado, por isso a datação é ainda uma hipótese baseada numa nota manuscrita pelo próprio inventor no alto da primeira página do documento.

16. Ver Daniel Pedro Müller (1838).

17. Data em que Florence anuncia, na Câmara Municipal de Campinas, o estabelecimento da autografia.

18. Ver Eliane Abrahão (2010).

19. Para um melhor entendimento da importância de Francisco Álvares Machado e Vasconcellos (1791-1846) na vida de Hercule, ver: Dirceu Ferreira e Nelson

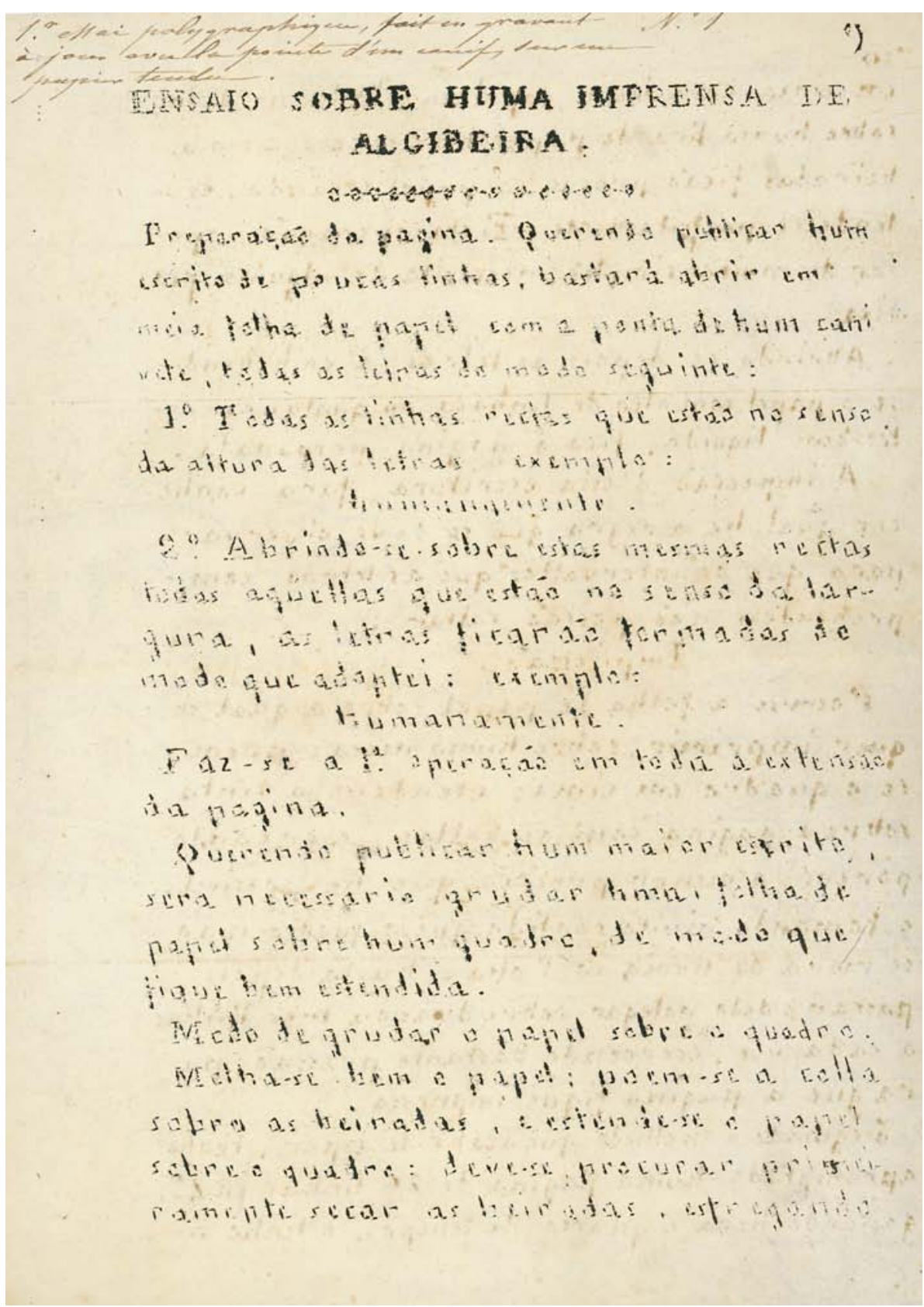

Figura 1 - Ensaio autográfico. Texło Ensaio sobre uma imprensa de algibeira, s/d. Acervo IMS/RJ. Código: O14FlorenceO1C.

A operação era bastante rudimentar quando comparada às conhecidas técnicas de impressão com pedra, madeira ou metal. Em termos qualitativos, a autografia não alcançava as técnicas de impressão que the eram contemporâneas; porém, os resultados e, principalmente, o sentido econômico da nova técnica 
estimularam seu inventor a continuar pesquisando materiais e métodos que pudessem tornar mais nítido o resultado da impressão.

As dificuldades da vida em São Paulo, contudo, levaram Florence a mudar-se com a família para a vila de São Carlos, distante cerca de 100 quilômetros da capital. Desde o final do século XVIII, essa região se beneficiava do excedente da produção de açúcar. A inversão de riqueza operada pelos senhores de engenho dotou a vila de um plantel de escravos significativo, em relação à população total. Daniel Pedro Müller registra no seu Ensaio ${ }^{16}$ uma população de 6.689 habitantes em 1837, dos quais 3.917 eram escravos. Quando, em 183217, Florence anunciou o estabelecimento de sua autografia, ele compartilhava o espaço central da próspera vila com farmacêuticos, músicos, marceneiros, carpinteiros, ferreiros, seleiros, ourives, alfaiates, sapateiros, caldeireiros e funileiros. Essa diversidade de funções assinalava uma dinâmica no mercado de trabalho dificilmente encontrada em outras vilas da província. $\bigcirc$ seu rápido crescimento econômico permitiu a elevação da vila ao status de cidade já em 1842, sendo, então, rebatizada com o nome de Campinas. As trocas comerciais, a convivência política (com destaque para o papel agregador da maçonaria), os planos de colonização e, posteriormente, a ligação ferroviária estreitaram os laços entre fazendas e vilas compreendidas pelo eixo CampinasLimeira-ltu-Sorocaba ${ }^{18}$. Iniciava-se ali a formação de um complexo políticoeconômico-cultural que desempenharia importante papel no processo de transição da monarquia para a república no Brasil.

Em São Carlos, Florence encontrou fonte de renda estável nos negócios do sogro, Francisco Álvares Machado e Vasconcellos, então afastado do interior paulista em função de sua carreira política ${ }^{19}$. Membro do Conselho Geral da Província, Álvares Machado foi Deputado Provincial e Deputado Geral do Império no período marcado pelos turbulentos anos da Regência ${ }^{20}$. Foi eleito Deputado Geral do Império por três vezes, obtendo assento na 3ª (1834-1837), 4 (18381840) e 6a (1845-1847) legislaturas ${ }^{21}$. Álvares Machado retornaria para a vida provincial em 1842, mas ficaria por pouco tempo, já que em 1845 voltou à Corte para tomar posse no cargo de Deputado Geral do Império. Nesse interregno, contou com seu prestimoso genro na administração de seus negócios: uma botica, uma loja de tecidos e a Fazenda Soledad.

Tanto melhor para Florence, pois a vida menos assoberbada do interior da província the permitiu avançar nas pesquisas. Seu primeiro caderno contendo anotações científicas sistemáticas, intitulado Livre d'annotations et de premiers matériaux, nos permite acompanhar a evolução das primeiras invenções. Entre as páginas 115 e 121 v, que registram os meses de junho e agosto de 1832, Florence detalhou os procedimentos da autografia. Como se verá a seguir, o sistema da "prensa de algibeira" rapidamente evoluiu para algo semelhante ao procedimento adotado na gravura em metal. $\bigcirc$ que Florence passou a denominar "autografia" era composto de três etapas: a preparação do 'papel autográfico', a preparação do molde e a impressão propriamente dita.
Cantarino (2009, p. 408413). Ou ainda a obra de Estevam Bourroul (1900).

20. O período regencial, compreendido entre a abdicação de d. Pedro I (7 de abril de 1831) e a maioridade de d. Pedro II (23 de julho de 1840), foi marcado pelo agravamento de manifestações e revoltas por todo Brasil. Além das quarteladas, rebeliões envolvendo escravos e quilombolas e manifestações lusófobas, e clodiram ainda movimentos separatistas no Sul e no Norte do Império, motivados pela questão da centralização $\quad X$ descentralização do poder político-administrativo.

21. Ver Estevam Bourroul (1900, p. 350). 
22. Aqui cabe destacar que, na explicação dos procedimentos para a produção da autografia, há muitas informações incompletas ou imprecisas. $\mathrm{O}$ inventor, por vezes, não fornece dados acerca das dimensões dos materiais empregados, ou mesmo o volume de cada elemento empregado na composição da tinta ou do verniz. A reprodução desses experimentos deve, assim, levar em consideração esse grau de imprecisão no relato de Florence.

\section{Preparação do papel autográfico 22}

Materiais

- placa de estanho ou cobre (Figura 2);

- recipiente de estanho ou cobre (Figura 3);

- espátula (Figura 4);

- duas folhas de papel (uma do tamanho da placa de cobre e outra um pouco maior):

- fuligem;

- goma arábica;

- cera;

- alvaiade;

- punção ou buril.

Procedimentos

1) Estender a folha de papel maior sobre a placa de estanho ou cobre (Figura 6), de modo que suas bordas excedam os limites da placa.

2) Dobrar as bordas do papel e colá-las no verso da placa.

3) Cobrir o verso da placa com a folha de papel menor, para proteger o metal das substâncias utilizadas no processo.

4) Preparar uma mistura de fuligem e goma arábica. Cobrir com ela a face do papel e reservar a sobra. Esperar secar o papel e passar mais uma camada de goma arábica, desta vez, sem fuligem. Essa segunda camada deve ser uniforme e espessa o suficiente para que fique com aparência lustrosa.

5) No recipiente de estanho ou cobre (Figura 7), preparar uma mistura de cera branca com alvaiade (blanc de plomb) e levá-la ao fogo brando até atingir o ponto de mistura. A ebulição pode provocar o aparecimento de algumas bolhas; portanto, após retirar o recipiente do fogo, desfazer as bolhas com uma espátula (figura 8), de modo que a mistura fique uniformemente distribuída pelo recipiente.

6) Esfriada a cera, colocar sobre ela a placa de estanho ou cobre, com a face engomada do papel preparado para baixo. A temperatura da cera deve ser cuidadosamente observada, pois o calor pode derreter a goma. $\bigcirc$ que se deseja, em vez disso, é que a cera se sobreponha à goma, formando sobre ela uma espessa camada.

7) Retirar cuidadosamente a placa do recipiente e deixá-la inclinada para escorrer o excesso de cera. Teremos, então, o papel autográfico formado por uma camada de goma com fuligem, uma camada de goma e outra, bem grossa, de cera com alvaiade.

8)Com um punção ou um buril, sulcar a cera para compor textos ou desenhos. Os sulcos devem ser suficientemente fundos para atingir a camada de goma, sem, contudo, ferir o papel. 


\section{Preparação do molde}

\section{Materiais}

- aparelho para impressão (Figura 5), composto por três peças sobrepostas;

- recipiente de madeira ou metal, com cerca de $1 \mathrm{~cm}$ de profundidade (figura 5);

- tecido bem fino (Figura 7), com dimensões idênticas às do recipiente de madeira;

- moldura para fixar as partes do aparelho (Figura 8);

- placa metálica com uma aba inclinada na extremidade superior (Figura 9). A parte plana da placa deve possuir as mesmas dimensões da superfície do recipiente de madeira (Figura 6);

- folha de papel um pouco maior que a placa metálica (Figura 9);

- recipiente de estanho ou cobre utilizado na preparação do papel autográfico

(Figura 3), tinta de impressão;

- fuligem;

- espátula (Figura 4);

- cera natural.
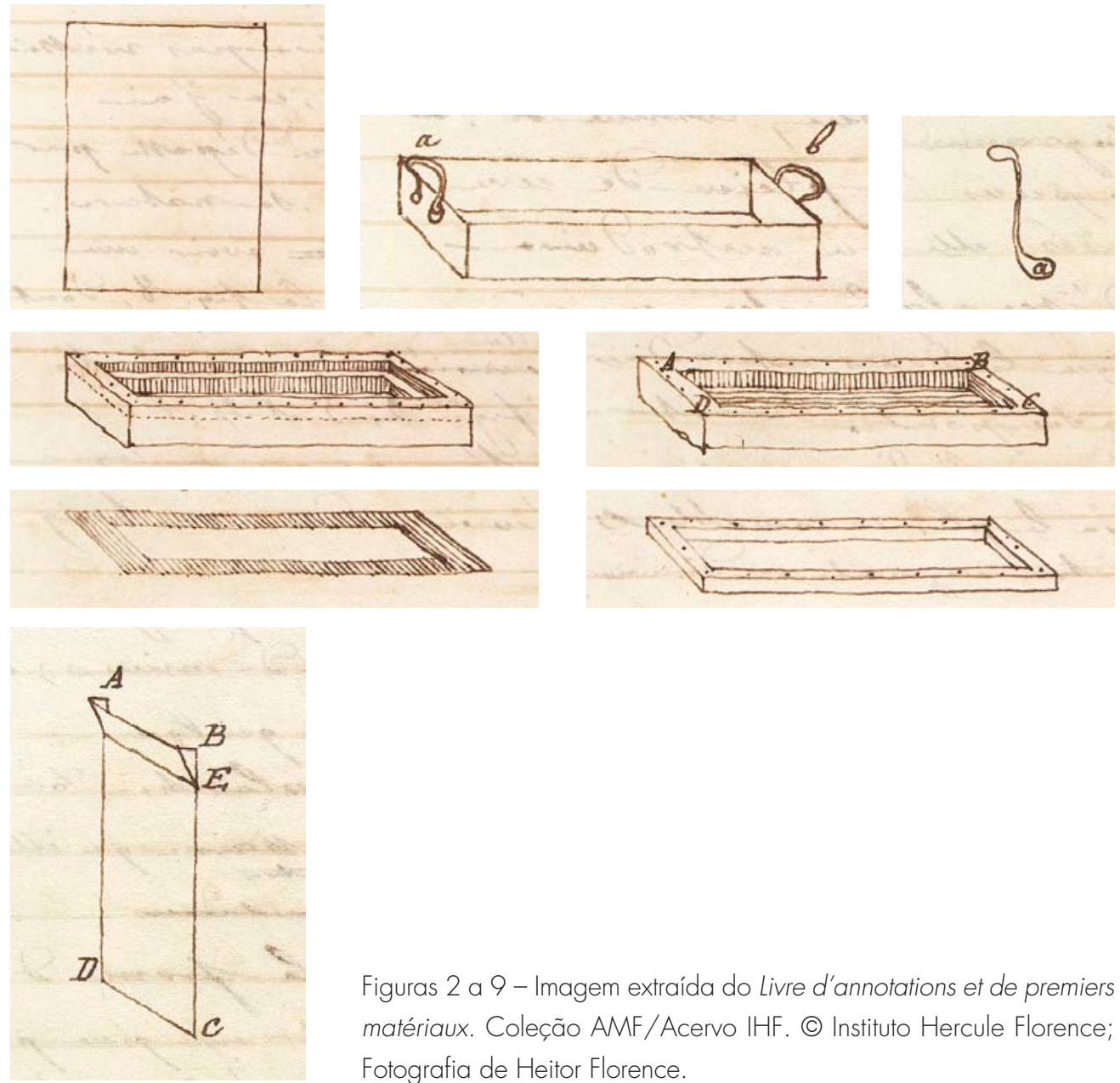

Figuras 2 a 9 - Imagem extraída do Livre d'annotations et de premiers matériaux. Coleção AMF/Acervo IHF. (C) Instituto Hercule Florence; Fotografia de Heitor Florence. 
Procedimentos

1) No recipiente de estanho ou cobre (Figura 3), misturar a cera e a tinta de impressão. Fundir a mistura em fogo brando, mexendo-a com uma espátula para que a tinta se mescle bem com a cera. Acrescentar fuligem à mistura para homogeneizar a cor. Depois de pronta a mistura, deixá-la esfriar.

2) Colar a folha de papel sobre a superfície da placa de metal (Figura 9), colando as bordas no verso.

3) Encaixar a placa de metal sobre o recipiente de madeira (Figura 6) com o papel virado para baixo, e a aba, para cima.

4) Utilizando a aba da placa de metal, despejar a mistura de tinta e cera dentro do recipiente de madeira. Após seu endurecimento, cortar as bordas do papel coladas na placa a fim de separá-la do recipiente. Lentamente, remover o papel que permaneceu sobre a tinta, cuidando para não deformar a superfície da mistura, que deve estar bem sólida e uniforme. Sobre esta peça, colocar um pedaço de tecido fino (Figura 7) e fixá-lo com a moldura (Figura 8), formando o aparelho para impressão (Figura 5).

5) Destacar o papel autografado da placa metálica (Figura 2) e colocá-lo sobre o aparelho para impressão com desenho ou a escrita para baixo. Fixar esse conjunto na prensa por cerca de dois minutos, com pressão suficiente para fazer a tinta penetrar os sulcos da cera, atingindo o papel com goma.

6) Com um pincel de cerdas flexíveis, umedecer o papel autográfico prensado no aparelho. Utilizar bastante água, de modo a dissolver a goma. Com um canivete, levantar um canto do papel com cuidado, evitando tocar a cera. Remover o papel lentamente e lavar com água o restante da goma para limpar a camada de cera. Estando perfeita a camada de cera, nela se verá o desenho ou o texto em posição invertida (negativo), em virtude da coloração escurecida da tinta. Com o pincel de cerdas flexíveis, agora bem seco, deve-se remover o resto de tinta da superfície da cera, que será utilizada como molde para as impressões.

3. Impressão

Materiais

- aparelho para impressão (Figura 5), ao qual foi prensado o molde de cera;

- folhas de papel para impressão.

Procedimento

Estender uma folha de papel seco sobre o molde de cera bem limpo e comprimir o conjunto na prensa para realizar a impressão.

Um dos primeiros registros da expressão "autografia" aparece na correspondência de Florence a Edouard Pontois, encarregado de negócios do governo francês no Brasil, com data de 2 de dezembro de 1831. Na carta, remetida de Santos (SP), Florence reivindica ao governo francês uma "recompensa" 
pela invenção. Sabe-se que M. Pontois encaminhou a correspondência de Florence ao Ministro dos Negócios Estrangeiros da França, conde de La Porta ${ }^{23}$. Maria Ines Turazzi aposta na hipótese de que os quarenta exemplares de desenhos e textos impressos pelo método da autografia, acompanhados de uma memória descritiva manuscrita por Florence, tenham chegado ao seu destino final. Porém, se houve ou não uma resposta do Ministro francês, ainda é uma incógnita.

A utilização comercial da nova invenção foi quase imediata. A 20 de maio de 1832, Florence enviou petição à Câmara Municipal de São Carlos anunciando o estabelecimento de sua "Autografia" para imprimir escritos e desenhos, na Rua do Rosário, casa nº2. À página 113 de seu Livre d'annotations et de premiers matériaux, apareceu menção ao relativo sucesso que Florence obteve na produção de cartas de crédito para Nicolau Pereira de Campos Vergueiro, bem como na impressão de cerca de 100 notificações encomendadas por "Mr. Boulte" 24 . Infelizmente, poucos foram os impressos autográficos que sobreviveram ao tempo. Os raros exemplares que restam encontram-se hoje sob a guarda do Instituto Moreira Salles (IMS), no Rio de Janeiro (Figura 10).

$\mathrm{Na}$ época em que relatou os procedimentos apresentados acima, reconheceu que a autografia não superava os métodos utilizados na gravura e na litografia. A impressão estava suscetível a erros, em especial no momento de separar a cera do papel, além do fato de a cera empregada no papel autográfico secar em poucos dias, o que não permitia o aprovisionamento das matrizes. Florence reputa essa limitação ao seu rudimentar conhecimento de química ${ }^{25}$. Contudo, a facilidade no aprendizado da aplicação do método e construção dos aparelhos, aliado ao baixo custo dos materiais empregados na autografia, o estimulou a perseguir seu aprimoramento.

No dia 12 de março de 1833, à página 146 do Livre d'annotations et de premiers matériaux, Florence descreve um "meio de imprimir estampas de modo que elas já saiam coloridas da impressão"26. Tal como descrito no diário, a impressão das cores nas estampas é uma continuação do procedimento iniciado com a impressão autográfica. Assim, sobre as cópias impressas a partir do aparelho da autografia, Florence efetuou uma segunda impressão a cores. $\bigcirc$ mesmo aparelho de impressão, ou matriz, utilizado na autografia foi usado para as primeiras impressões em preto. Em seguida, um segundo aparelho, construído de forma idêntica ao primeiro, serviu para a impressão colorida. Neste último, cada parte do aparelho recebeu uma coloração diferente, conforme o interesse do inventor em fazer imprimir, ao mesmo tempo, diferentes cores sobre a estampa.

A invenção e a evolução para o método de "impressão simultânea de todas as cores" 27 exigia a criação de nomenclatura específica e, a partir do dia 15 de março de $1834^{28}$, a expressão "poligrafia" aparece nos registros relativos a essa técnica de impressão. Após essa data, Florence não mencionou mais o nome "autografia" em cartas, plaquetes, prospectos ou memorandos dedicados à divulgação da invenção. Em seguida, no esforço de organizar seus manuscritos primevos, Florence os identificou com a nova nomenclatura. É assim que se explica o fato de os manuscritos de 1830
23. Conde de La Porta: Horace François Bastien Sébastiani (1771-1851). Cf. Maria Inez Turazzi (2008, p 24).

24. É provável que Hercule tenha produzido esse material para o relojoeiro Dieu-donné Boulte Dillon, estabelecido na Capital da Província de São Paulo nos anos 1830. Sobre este há um anúncio no jornal $A$ Phenix (26 set. 1838).

25. Cf. Hercule Florence (1830-1835, p. 125).

26. Traduzido a partir do título do registro: "Moyen d'imprimer des estampes de manière à ce qu'elles sortent déjà coloriées de l'impression".

27. A frase é recorrente nos manuscritos de Florence quando se refere à poligrafia.

28. Cf. Hercule Florence (1830-1835, p. 160). 
29. Estevam Leão Bourroul erroneamente atribuiu a invenção da poligrafia ao ano de 1830. Cf. Estevam Bourroul (1900, p. 418).

30. Traduzido do francês: "1er essai polygraphique, fait en gravant à jour avec la pointe d'un canif, sur un papier tendu". Acervo IMS/ RJ. Código: 014Florence01C.

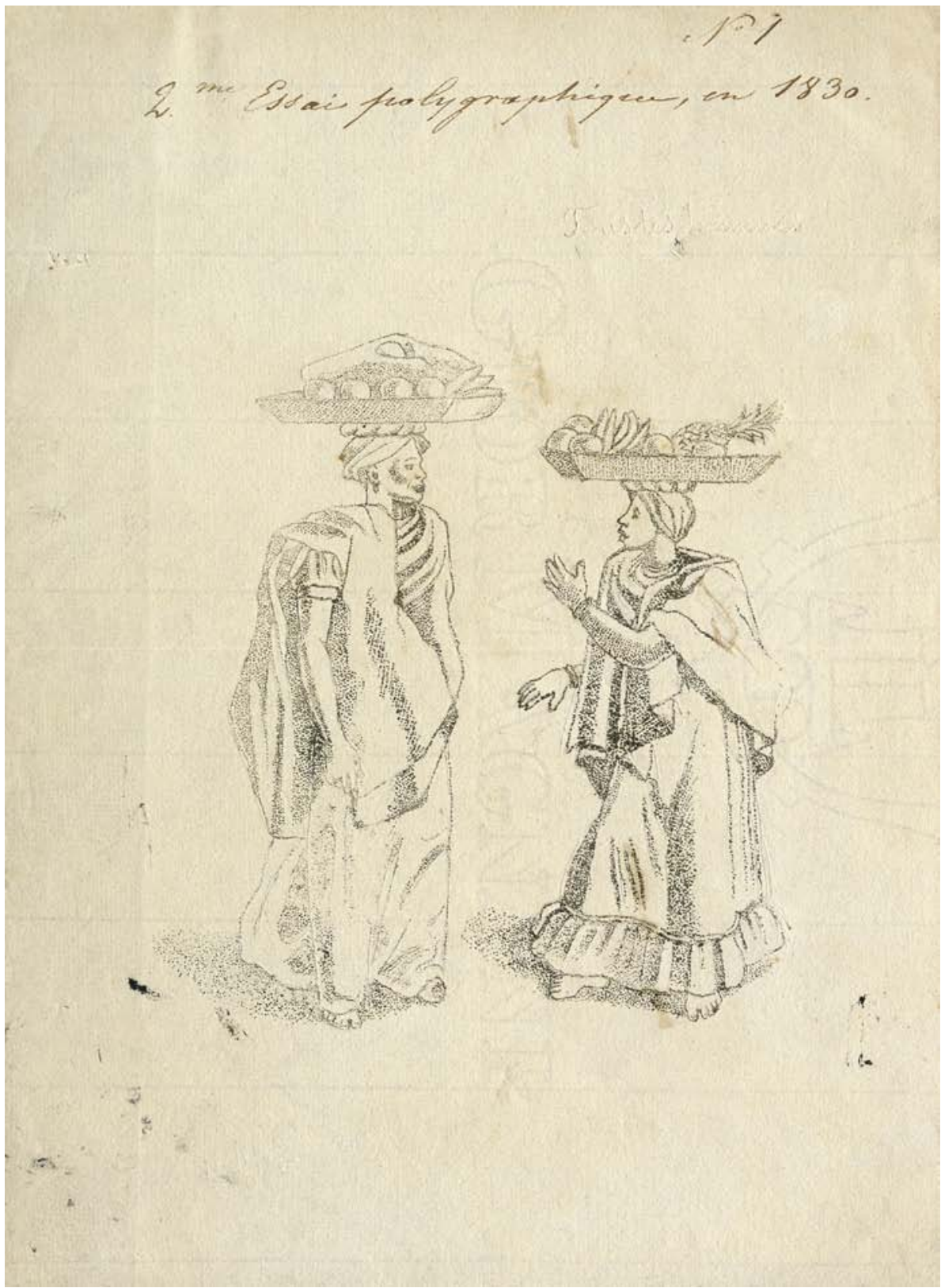

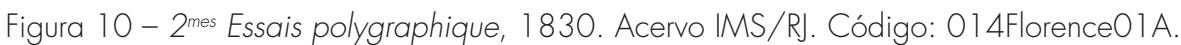

e 1831 terem sido classificados como "ensaios poligráficos", quando o inventor ainda não buscava fazer impressão a cores ${ }^{29}$. Por exemplo, no topo da página do documento intitulado Ensaio sobre huma imprensa de algibeira, impresso autográfico de 1830, Florence manuscreveu: "N. 1. $1^{\circ}$ ensaio poligráfico, feito por gravação com a ponta de um canivete, sobre um papel esticado" 30 . Outro exemplo em que o nome "poligrafia" é atribuído a impressos autográficos está no próprio Livre d'annotations et de premiers matériaux, quando Florence explica o procedimento da autografia, na página 110 
(Figura 1 1), em julho de 1832; observa-se que, à margem do texto principal, destacado por um colchete, ele registrou o nome poligraphie. Neste caso, o autor indicou um forte vínculo entre os experimentos da autografia e os que resultariam na invenção da poligrafia, tempos depois. Como também se nota no exemplo a seguir, em que à margem do texto há uma identificação delimitada por uma grande chave. O trecho é identificado como parte das anotações relativas à evolução da poligrafia. Já no corpo do texto, o inventor refere-se ao papel "Auth.", de autográfico.

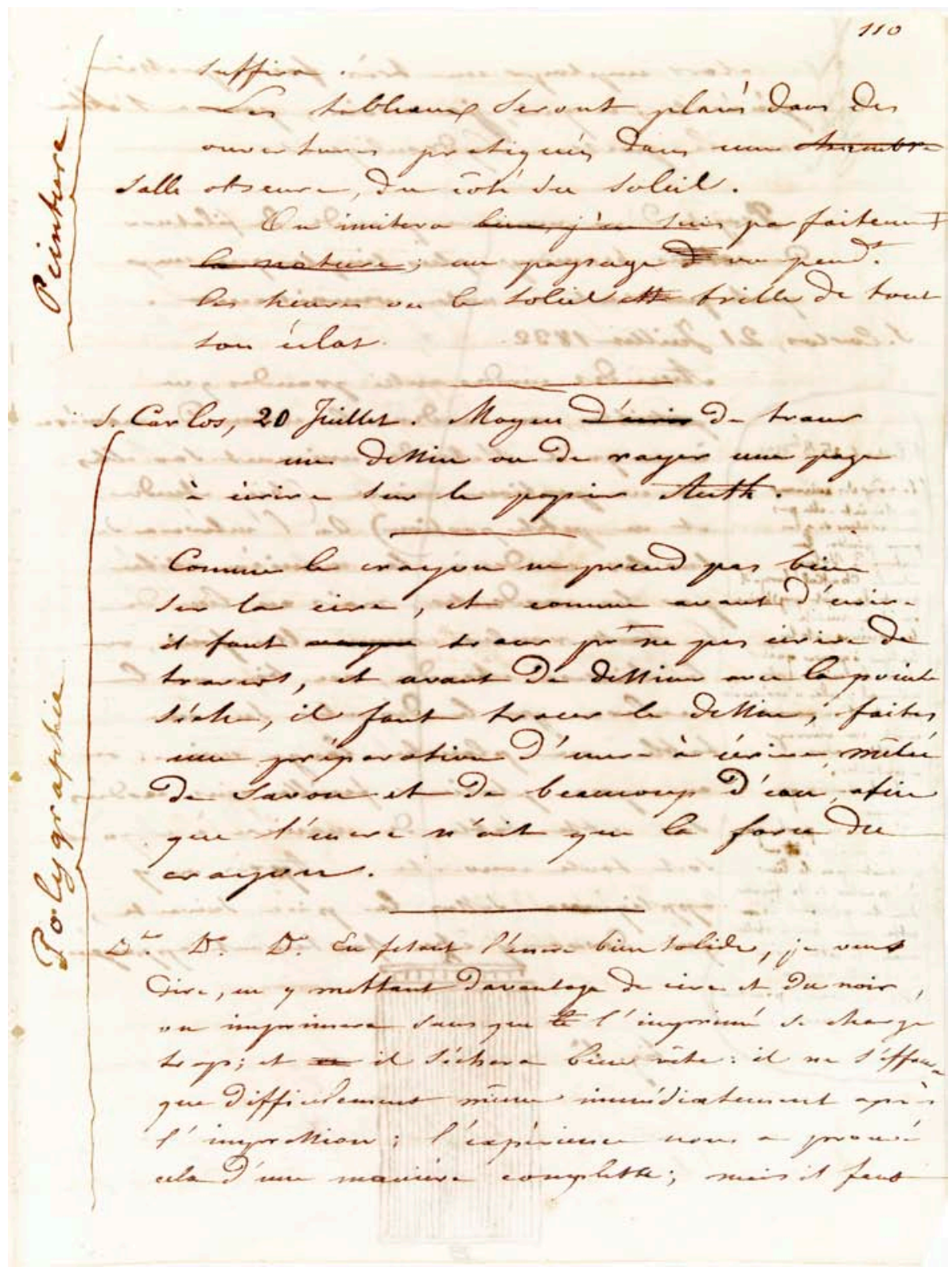

Figura 11 - Livre d'annotations et de premiers matériaux, p. 110. Coleção AMF/Acervo IHF. (c) Instituto Hercule Florence; Fotografia: Heitor Florence ${ }^{31}$.
31. Transcrição: "S. Carlos, 20 Juillet. Moyen d'unir de tracer un dessin ou de rayer une page à écrire sur le papier Auth. Comme le crayon ne prend pas bien sur la cire, et comme avant d'écrire il faut rayer tracer $p r+$ ne pas écrire de travers, et avant de dessiner avec la pointe sèche, il faut tracer le dessin, faites une préparation d'encre à écrire, mêlée de savon et de beaucoup d'eau, afin que l'encre n'ait que la force du crayon". 
32. Doc. "Descuberta da polygraphia. Circular. S. Carlos 1834 Polygraphia de Hercules Florence". Acervo I M S / R J C Código: 014Florence04. Anúncio em cinco cores.

33. Ver Daniel Pedro Müller (1838).

34. Boris Kossoy, em $A$ descoberta isolada da fotografia no Brasil, menciona uma carta de Florence ao jornalista Evaristo da Veiga, de 29 de setembro de 1832, ainda em forma de rascunho no caderno Brouillard n. 1; cita ainda artigos sobre a poligrafia publicados em 1839 nos jornais A Phenix e Observador paulistano, republicados em 29 de dezembro de 1839 pelo Jornal do Commercio. Em 1842, Florence se regozija com a iniciativa do encarregado de negócios do Reino da Sardenha no Brasil, Alexandre Allouat. Este enviou um memorando sobre a poligrafia para a Academia de Ciências de Turim. Estevam Leão Bourroul (1900) menciona que os responsáveis pela avaliação da invenção sugeriram que ela merecia a proteção do Governo da Sardenha. Informação que o próprio Florence contrariou em correspondência a Charles Taunay (citada acima). Nesta, Florence dizia que a Academia de Ciências de Turim declarou que a poligrafia já era conhecida, e que ele apenas a aperfeiçoara. O jornal Correio Mercantil, do Rio de Janeiro, também publicou uma descrição da poligrafia em 11 de dezembro de 1851 e 18 de janeiro de 1852 (em francês). Florence menciona ainda que sua invenção fora registrada na Academia de Belas Artes do Rio de Janeiro em 1844 (Cf. Découverte de la Polygraphie. Notice sur la Polygraphie. $1^{\text {er }}$ août 1853, Acervo Iconográfico, BNRJ). sentido comercial dado à autografia foi também herdado pela poligrafia e, ainda em 1834, Florence imprimiu uma circular divulgando a invenção aos "Negociantes, Fabricantes, Farmacêuticos e a todas as pessoas que precisam mandar imprimir, que ele [Florence] imprime anúncios, letras, circulares, letreiros para vidros e garrafas, bilhetes, guias para tropeiros, recibos de açucares e café, e tudo o mais que se possa precisar" 32 (Figura 12). Logo a notícia se espalhou pela província e Florence começou a receber propostas de trabalho. Publicou anúncios para casas comerciais e pequenos fabricantes. Em 1836, o marechal engenheiro Daniel Pedro Müller requisitou a Florence a impressão de um mapa das rotas da Província de São Paulo. Feito pelo método da poligrafia, o mapa foi incluído em obra oficial contendo os quadros estatísticos da província ${ }^{33}$.

Em L'ami des arts há uma explicação detalhada do processo da poligrafia, tal qual Florence o fizera evoluir até o final dos anos 1830. Ali, o leitor encontrará a lista dos materiais, as técnicas empregadas e a descrição dos procedimentos para realização da impressão poligráfica. Antes e após a redação dessa explicação da poligrafia, Florence redigiu algumas correspondências e artigos para jornais na tentativa de divulgar sua invenção ${ }^{34}$. A última publicação dedicada à divulgação da poligrafia foi impressa em Santos, na Typographia Commercial de G. Delius, em 1858, com o título Invenção da Poligrafia por Hercules Florence. Comparada ao procedimento apresentado em L'ami des arts, a explicação da poligrafia de 1858 revela diferenças técnicas significativas. A apresentação a seguir foi baseada nessa plaquete.

\section{Preparação das tintas: poligráfica e coloridas ${ }^{35}$}

\section{Materiais}

- 3 kg de sabão de potássio36;

- $1 \mathrm{~kg}$ de tinta tipográfica;

- água;

- fuligem;

- óleo de linhaça;

- tintas coloridas;

- coador de pano fino;

- panela;

- moedor de pedra.

Procedimentos para a tinta poligráfica

1) Sob fogo brando, dissolver 3 kg de sabão de potássio em uma panela com água.

$\bigcirc$ processo leva cerca de 2 horas e deve-se mexer a mistura com uma espátula.

2) Juntar ao sabão dissolvido, na mesma panela, $1 \mathrm{~kg}$ de tinta tipográfica. Mexer até fundir completamente as duas misturas, acrescentando água sempre que a mistura ficar espessa. 


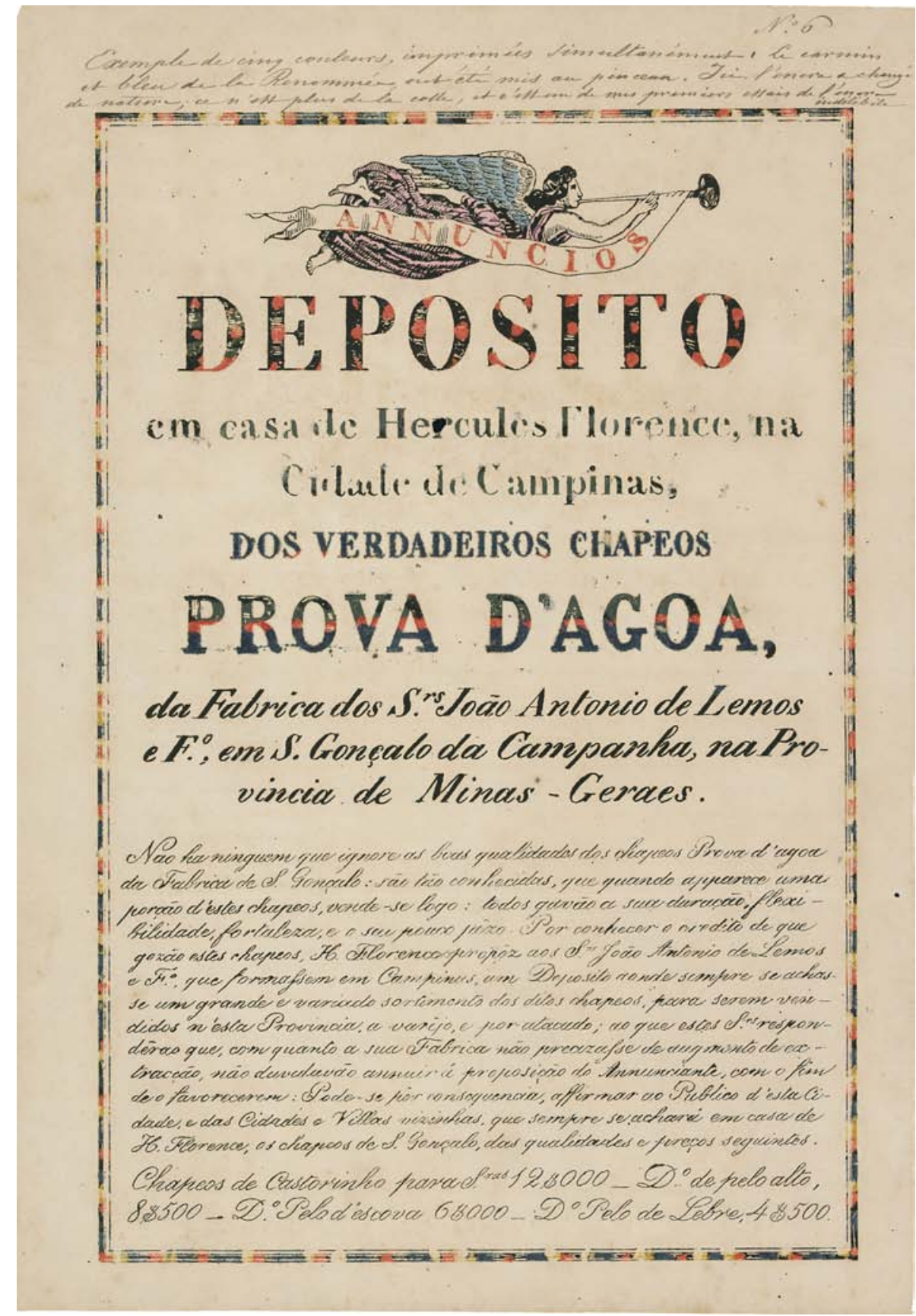

Figura 12 - Poligrafia. Anúncio em cinco cores da Fábrica de Chapéus São Gonçalo, na Província de Minas Gerais. Campinas, SP, s/d. Acervo IMS/RJ. Código: O14Florence06.

3) No caso de a mistura não ficar totalmente preta, deve-se separar uma porção de 40 a 50 gramas, misturar com fuligem e retornar ao fogo, mexendo até formar uma mistura de cor homogênea. Deve-se evitar o excesso de fuligem, pois a tinta fica menos solúvel.
35. Para explicar o procedimento da poligrafia foram utilizados dois textos como referência: Découverte de la polygraphie par Hercule Florence (1853) e Invenção da Poligrafia por Hercules Florence. Hercule Florence, (1858). O primeiro é uma memória impressa pelo método da poligrafia e está arquivada na Biblioteca Nacional do Rio de Janeiro. O segundo é uma tradução do primeiro, aumentada, corrigida e publicada em Santos pela Tipografia Comercial, hoje arquivada no Acervo do Instituto Hercule Florence, em São paulo.

36. Nota-se aqui um aspecto primordial na evolução da poligrafia. Na explicação de 1837, apresentada no L'ami des arts à página 22 , Florence usa cola-forte, água e fuligem para a preparação da tinta poligráfica. A cola-forte, substituída pelo sabão de potássio no texto de 1853 , apresentava dois inconvenientes: se decompunha rapidamente ao fogo e era muito solúvel em água. 
37. Assim como na explicação dos procedimentos da autografia, Florence não fornece detalhes dos materiais empregados, como a dimensão das placas de vidro, tipo e tamanho dos papéis, etc.
4) Coar em pano fino toda a tinta fundida, de modo a eliminar as partes heterogêneas da mistura.

5) Sobre uma mesa bem limpa, estender a tinta para secagem. Esse processo pode durar até 24 horas, variando conforme a concentração de água na mistura. A tinta deve atingir a consistência de manteiga, menos denso que o sabão de potássio. Florence alerta para não deixá-la muito mole, para não empastar na impressão, e nem muito dura, para não dificultar a execução das provas.

6) Após essa operação a tinta deve ser moída, pois a secagem não ocorre de maneira uniforme e a tinta deve ser homogênea em todos os sentidos. Reservar dentro da panela fechada, evitando contato com o ar.

Procedimentos para a tinta colorida

1) Cozinhar o óleo de linhaça até atingir o ponto de melado.

2) Moer as diferentes tintas coloridas e misturá-las a esse excipiente, em recipientes separados.

2. Preparação do molde

Materiais

- placas de vidro ${ }^{37}$;

- folhas de papel lum pouco maior que a placa de vidro, de modo a permitir que se grude as bordas da folha no verso da placa);

- papel;

- punção ou buril (de várias formas e tamanhos, variando conforme o desenho ou o texto que se quer gravar);

- pincel seco;

- espátula convexa;

- rama A (bastidor);

- gaze;

- balas de impressão de 4 a 5 centímetros de diâmetro (2 unidades);

- fuligem;

- goma arábica;

- cera natural (8 gramas);

- óleo de linhaça (1 grama);

- alvaiade (5 gramas);

- terebintina;

- essência de terebintina (4 gramas);

- vermelhão (2 gramas);

- tinta poligráfica.

Procedimentos

1) Estender a folha de papel sobre a placa vidro, de modo que suas bordas excedam os limites da placa (Figura 6). Dobrar as bordas do papel e colá-las no verso da placa. 
2) Preparar uma mistura de fuligem e goma arábica. Cobrir a face do papel com essa mistura. Esperar secar o papel e passar mais uma camada de goma arábica, desta vez sem, fuligem. Essa segunda camada deve ser uniforme e espessa o suficiente para que fique com aparência lustrosa, como um verniz.

3) Preparar uma mistura de 5 gramas de alvaiade moído (blanc de plomb) com 1 grama de óleo de linhaça; cozinhar a mistura como se procede com a tinta tipográfica e juntar cera derretida na porção de 4 gramas mexendo ao fogo brando até atingir o ponto de mistura. Despejar essa mistura num cilindro feito de papel. Esperar a mistura secar e esfriar para, só então, retirar o papel. A mistura agora terá adquirido a forma do cilindro.

4) Esfregar o cilindro sobre o papel engomado até formar sobre a goma uma camada de massa. Esta deve ser uniformizada com uma espátula convexa aquecida à luz de vela. Para eliminar a viscosidade da massa, deve-se colocar sobre ela um tecido fino embebido em essência de terebintina e, levemente, pressioná-lo com os dedos. Retirar o tecido e esperar secar: a massa estará pronta para receber a gravação, pois terá uma consistência rígida.

5) Com um punção ou um buril deve-se compor os textos ou desenhos, sulcando a massa (camada branca sobre a goma) como se procede com as gravuras em metal. Os sulcos devem ser suficientemente fundos para atingir a camada de goma, sem, contudo, ferir o papel. Os traços feitos com o buril deixarão visível a camada de goma arábica, que se destaca do branco da massa por sua cor preta. Reservar a gravura. 6) Fixar uma gaze (ou garça) em uma rama $A$ de tamanho um pouco maior que o da placa de vidro onde se fixou o papel.

7) Misturar 4 gramas de cera com 2 gramas de terebintina colorida com vermelhão. Fundir a mistura ao fogo. Apagar o fogo e misturar 4 gramas de essência de terebintina. Esse verniz deverá ser colocado sobre a massa na qual se traçou o texto ou o desenho, de modo suficientemente cuidadoso para não obstruir seus traços. Para tanto, usam-se balas de impressão de 4 a 5 centímetros de diâmetro, de modo semelhante à operação de colocar a tinta sobre os tipos. O objetivo é restaurar a viscosidade da superfície da massa. $\bigcirc$ vermelhão permitirá identificar as quantidades de cera colocadas sobre a superfície, devendo servir para uniformizar a camada de verniz.

8) Separar o papel, gravado e envernizado, da placa de vidro. Colocá-lo sobre uma placa de madeira (tábua) plana, deixando à vista a gravação.

9) Com bastante cuidado, colocar a rama A com gaze sobre o papel gravado. Esfregar a gaze de modo a aderi-la à superfície viscosa do papel. Deve-se verificar se a gaze está bem colada à superfície, o que pode ser feito com um canivete. Assim, forma-se um conjunto com o papel gravado fixado à rama $A$.

10) Despejar sobre essa superfície uma camada de tinta poligráfica, que deve atravessar a gaze e penetrar nos sulcos da gravura.

11 ) Depois de seco, deve-se dispor o conjunto (papel gravado fixado na rama A) sobre duas ripas de madeira fixadas à mesa, de modo que a superfície gravada fique com a face voltada para baixo, porém a uma distância de dois ou três dedos da mesa. Em seguida, deve-se molhar o papel com um pincel, para dissolver a 
goma arábica interposta entre este e a camada que contém a gravação. Após dissolvida toda a goma, deve-se cuidadosamente retirar o papel, revelando a gravura no sentido inverso. $\bigcirc$ molde estará pronto, com a tinta poligráfica impregnada à massa que contém a gravura, e esta fixada na rama $A$.

\section{Forma poligráfica}

\section{Materiais}

- rama $B$ : da mesma espessura da rama $A$ (na qual está fixada a gravura) e que se encaixe perfeitamente dentro dela, segundo a figura a seguir (Figura 13);

- folhas de papelão fino que se encaixem perfeitamente no interior da rama B;

- folhas com as mesmas dimensões das de papelão, que serão reservadas;

- prensa (Figura 14 - fig. 1e);

- rasoura;

- espátula;

- cera natural.

Procedimentos

1) Fazer um fundo para a rama $B$ com as folhas de papelão fino, unidas umas às outras com cera natural. $\bigcirc$ fundo deve preencher metade da espessura da rama $B$; 2) Colocar a rama $B$ sobre a mesa do trem da prensa (figura 14 - fig. 2e).

3) Despejar a tinta poligráfica no interior da rama B. Com uma rasoura, nivelar a superfície da tinta para que fique plana. Limpar as bordas da rama e deixe secar por alguns minutos.

4) Estender sobre a rama B um tecido fino, como a gaze, cuidando para que fique bem fixo. Se possível, este tecido deve ser metálico e fino.

5) Encaixar a rama $A$ (que contém a gravura) na rama $B$, de modo que a gravura fique em contato com a tinta poligráfica. Estará pronta a forma poligráfica. (Figura 13)

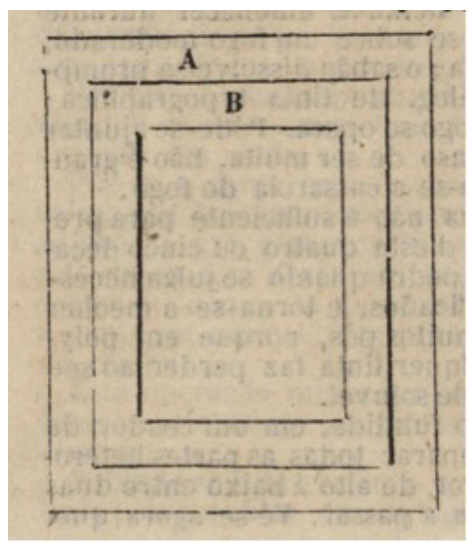

Figura 13 - Extraída de Invenção da Poligrafia por Hercules Florence. Santos: Typographia Commercial de G. Delius, 1858/Acervo IHF. (C) Instituto Hercule Florence; Fotografia: Heitor Florence. 


\section{Impressão}

\section{Materiais}

- prensa (Figura 14 - fig. 1e);

- folhas de papel para impressão embebidos em líquido de propriedade solvente.

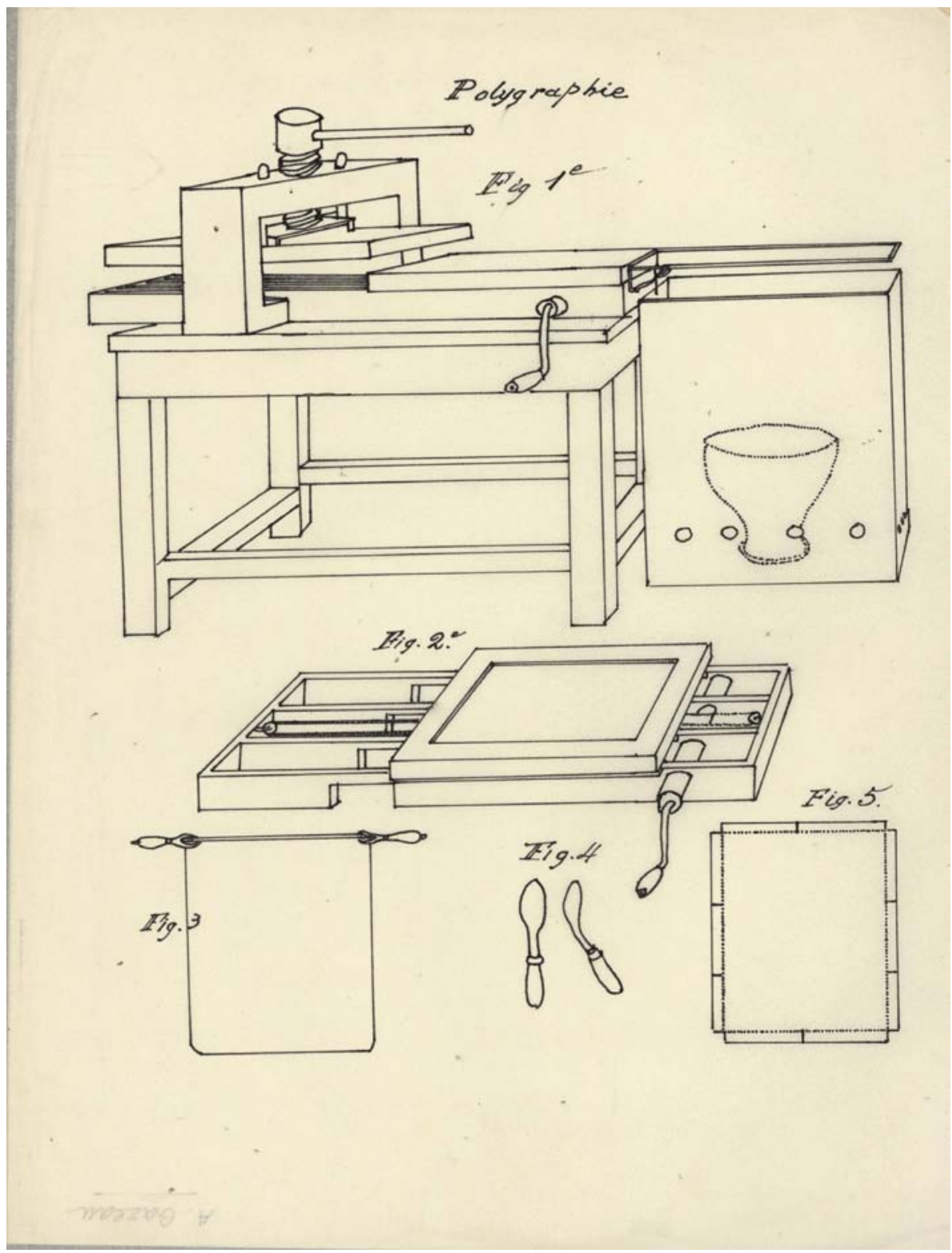

Figura 14 - Polygraphie. Cópia desenhada por Arnaldo Machado Florence, a partir do original de Hercule Florence. Coleção AMF/Acervo IHF. (c) Instituto Hercule Florence; Fotografia: Heitor Florence. 
38. A explicação mais detalhada do processo de impressão do papelinimitável encontra-se no L'ami des arts, página 114. Infelizmente, a imagem da "placa inimitável" foi destacada do manuscrito original e se perdeu. Logo, o leitor não poderá visualizar o desenho da mesma. Porém, as explicações do inventor são suficientemente claras e os materiais não diferem daqueles utilizados na autografia.

\section{Procedimento}

1) Estender uma folha de papel umedecida sobre a forma poligráfica e comprimir o conjunto na prensa. Na primeira impressão, manter a prensa sobre a forma durante alguns minutos, para que a tinta possa ser dissolvida e impregnada ao papel. Para as demais impressões essa medida não é necessária e o papel deverá ser retirado rapidamente, evitando a secagem da tinta.

2) $\bigcirc$ papel usado na primeira impressão deve ser bastante úmido. $\bigcirc$ grau de umidade dos demais deve variar conforme a impressão. Quando as provas ficam muito empastadas, deve-se diminuir a umidade do papel, e vice-versa.

3) Quando a impressão for suspensa a forma poligráfica deve ser coberta com um papel úmido e um papel oleoso.

4) Não é necessário renovar a tinta durante a impressão, pois esta é posta em massa sob a gravura, cujos traços são atravessados pela tinta.

5) A impressão a cores é feita após a secagem da primeira impressão feita com tinta poligráfica. Nos sulcos da gravura colocada na forma poligráfica, deve-se escolher os lugares onde se quer fazer imprimir cada uma das cores. Esses lugares devem ser marcados sobre a tinta poligráfica presente na forma. Em seguida, retirase a tinta poligráfica dos lugares marcados, cuidadosamente. Nos sulcos formados pela remoção da tinta poligráfica introduzem-se as tintas coloridas que serão impressas no papel.

6) É possível imprimir 120 (cento e vinte) cópias em uma hora de trabalho, seguindo os passos descritos acima.

Dos experimentos que resultaram na impressão simultânea de cores derivou ainda a invenção do papel-inimitáve ${ }^{38}$ e da pulvografia. $\bigcirc$ papel-inimitável tinha uma aplicação comercial evidente: visava atender à necessidade dos bancos de imprimir um tipo de papel-moeda que não pudesse ser falsificado. Para fabricar esse papel, Florence utilizou os mesmos materiais empregados na poligrafia, mencionados acima. A diferença fundamental está na construção da "placa inimitável" no lugar da "forma poligráfica". Florence fundiu aleatoriamente diferentes cores numa solução gelatinosa formada pelo cozimento de uma mistura de cola e água. A massa pastosa, resultante dessa operação, foi, em seguida, depositada no interior de um recipiente. A mistura aleatória de cores que se formava no recipiente era, então, impressa no papel. $\bigcirc$ resultado era um tipo de papel marmorizado, inimitável (Figura 15).

Fotografia

No mesmo Livre d'annotations et de premiers matériaux, poucas páginas após a demonstração da autografia, Florence prevê o desenvolvimento de um método de impressão pela ação da luz sobre o nitrato de prata. $\bigcirc$ texto abaixo, datado de 15 de janeiro de 1833, relaciona esse novo método à palavra photographie. (Figura 16) 

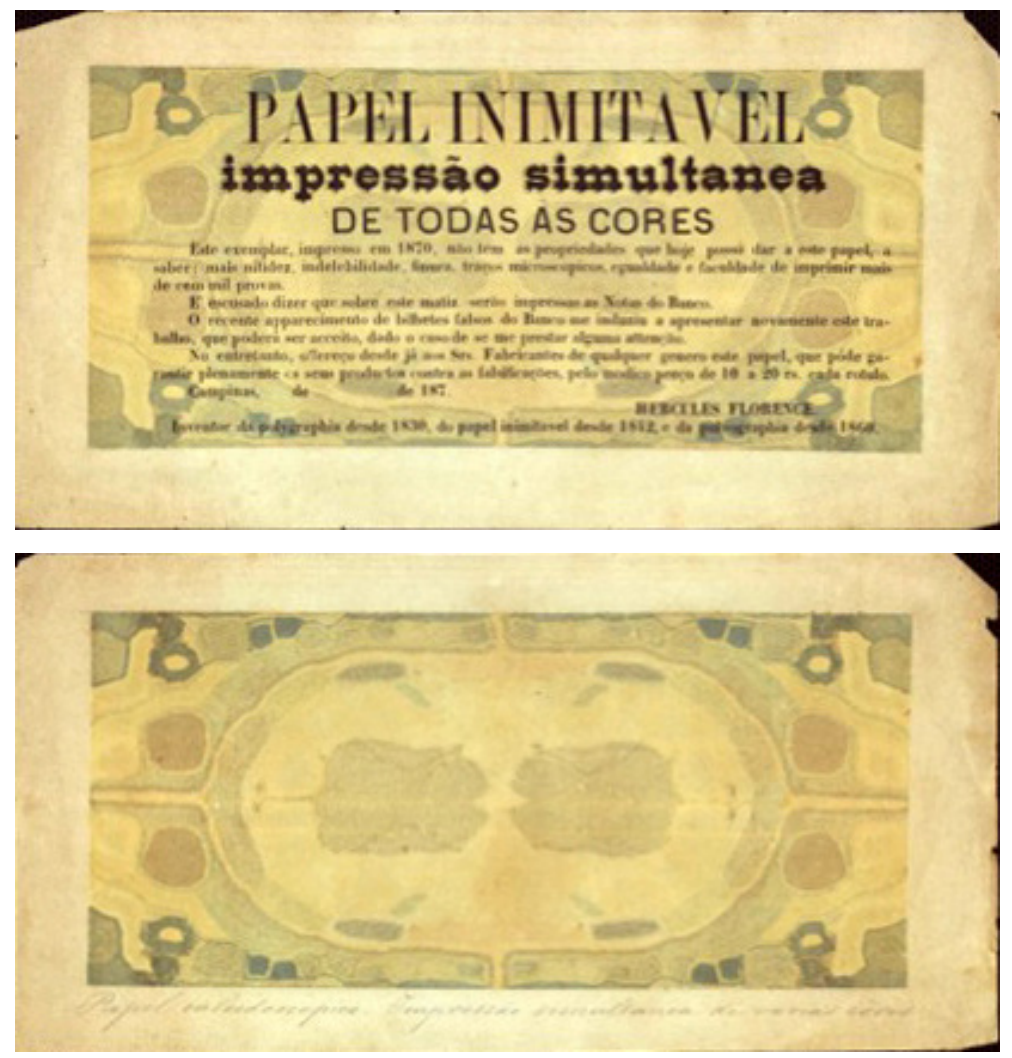

Figura 15 - Papel inimitável. Acervo lconográfico / BNRJ.

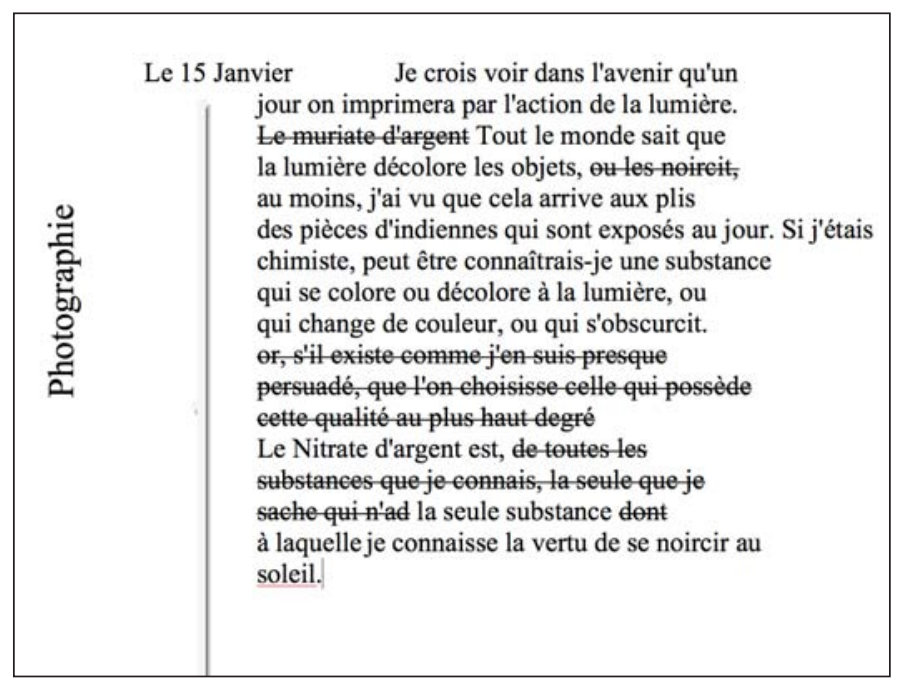

Figura 16 - Transcrição do Livre d'annotations et de premiers matériaux, p. 115. 
39. "Fotografia. 15 de Janeiro. Eu acredito que no futuro poderemos imprimir pela ação da luz. Өetoreto de prata Todo o mundo sabe que a luz descolore os objetos, ou os esetrece, pelo menos foi o que ocorreu com as dobras das peças indianas que foram expostas ao sol. Se eu fosse químico, talvez conhecesse uma substância que se colore ou que se descolore sob a luz, ou que muda de cor, ou que escurece. ora, se ela existe, como estot quase persuadido, temos que escolher aquela que posstri essa qualidacte no grau mais elevado $\mathrm{O}$ nitrato de prata é, de todas as substaneias que eonheço, a úniea que sei a única substancia cuja à qual eu conheço a virtude de se escurecer sob a luz do sol"
Reproduz-se, nessa transcrição, a diagramação original do caderno de anotações, com rasuras e notas colocadas às margens ${ }^{39}$. Nota-se aí um padrão que se repete em todo o manuscrito: à margem do texto, um colchete delimita a parte do texto identificada pela palavra escrita em sentido vertical (photographie), manuscrita em época posterior à do texto principal, conforme atestam o estado de conservação da tinta e a comparação com as demais páginas do manuscrito. $\mathrm{Na}$ página 114 do Livre d'annotations et de premiers matériaux (Figura 17) há uma

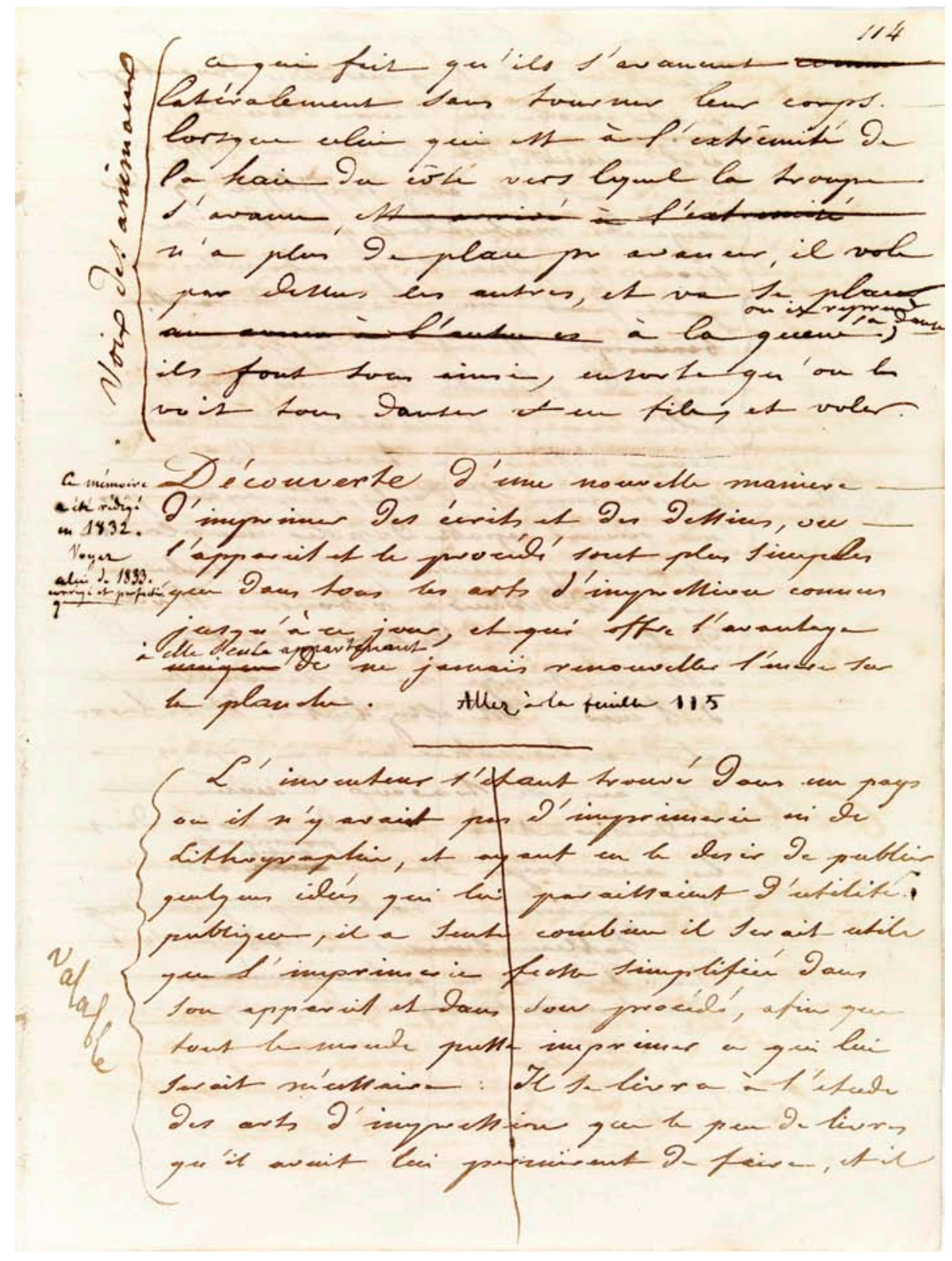

Figura 17 - Extraída de Livre d'annotations et de premiers matériaux, p. 114. Coleção AMF/ Acervo IHF. ( ) Instituto Hercule Florence; Fotografia de Heitor Florence. 
observação anotada à margem do texto indicando que o mesmo foi revisto e reordenado por seu autor. Florence diz explicitamente: "Este memorando foi escrito em 1832. Veja o de 1833, corrigido e aperfeiçoado".

Além de revisar o manuscrito em que registrou suas invenções, o autor sugere que se ignore as anotações mais antigas e se vá direto àquelas corrigidas e aperfeiçoadas no decorrer das pesquisas. Essa indução do olhar do leitor é obra posterior, em que o inventor, já ciente dos resultados da investigação, remonta os passos da pesquisa e reorganiza suas ideias a fim de compilá-las num texto definitivo. Este seria apresentado ao público no formato do L'ami des arts, cuja redação foi concluída em 1859.

Essas anotações feitas a posteriori indicam que Florence iniciou a redação do L'ami des arts em 1837 tomando seus próprios diários como base para compor um texto coeso, que explica em detalhes os passos de cada invenção. Portanto, a marginália dos manuscritos do início dos anos 1830 teriam sido feitas a título de organização das ideias apresentadas cronologicamente no L'ami des arts. Boris Kossoy percebeu com acuidade a proximidade entre os textos dos rascunhos primevos e aqueles compilados no L'ami des arts. À página 200 de seu Hercule Florence: a descoberta isolada da fotografia no Brasil, diz:

Nossa análise se fundamenta em suas anotações do dia-a-dia. Assim, pelas páginas dos manuscritos, pode-se perceber que Florence assinalava, ao lado dos textos, o tema a que se referiam. No que concerne às suas anotações acerca das experiências com a fotografia, observa-se com frequência, sempre ao lado desses textos, os seguintes títulos: fixation des images dans la chambre obscure e photographie, sendo este último termo empregado em seus processos de impressão de papéis fotossensíveis mediante a ação da luz solar. Tais títulos podem ter sido assinalados ao mesmo tempo em que fazia as anotações, isto é, a partir de janeiro de 1833; poderiam também, ter sido escritos posteriormente ${ }^{40}$.

Kossoy considera que a palavra photographie poderia ter sido utilizada ao longo dos experimentos de 1833. Porém, a leitura paleográfica do manuscrito traz à luz nova possibilidade de interpretação e datação. Como dito acima, as anotações à margem obedecem a um padrão de registro diferente do adotado no texto principal ${ }^{41}$. Diante disso, pode-se reler o Livre d'annotations et de premiers matériaux examinando com cautela os termos e procedimentos que seu autor empregou na invenção da fotografia.

Entre os dias 15 e 20 de janeiro de 1833, Florence fez diferentes experiências com o nitrato de prata. Na primeira, construiu uma câmara obscura bastante rústica, com paleta de pintura e lente de monóculo. Muito imperfeita, essa câmara não permitiu a formação de uma imagem exata no papel embebido em nitrato de prata. Dispensou esse material e foi buscar um pedaço de telha de vidro. Enegreceu a telha com fumaça de vela e, com um punção, escreveu: Et toi Divin soleil, prête-moi tes rayons. Colocou embaixo da telha um pedaço de papel embebido em nitrato de prata e expôs o conjunto ao sol por alguns minutos. Viu
40. Cf. Boris Kossoy (2006, p.200). Itálico nosso.

41. Interessado em reconstituir a invenção da fotografia por Hercule Florence, Boris Kossoy dedicou-se à leitura cuidadosa do manuscrito Livre d'annotations et de premiers matériaux, tendo dedicado atenção especial aos registros de e após 15 de janeiro de 1833. Isso explica, em parte, por que, em seu livro, a palavra "autografia" não é citada. Se, em sua leitura do manuscrito, Kossoy privilegiou os registros feitos à margem do texto principal para identificar as referências às pesquisas conduzidas por Florence, é plenamente compreensível o motivo pelo qual confundiu como parte da "poligrafia" um texto que, na verdade, referia-se à invenção da "autografia". Como explicado acima, a partir de 1834, Florence abandona o nome "autografia", pois se tornara inadequado para identificar a "impressão simultânea de todas as cores". Em decorrência disso, Florence organizou seus escritos, fazendo notas à margem do texto com base nessa nova nomenclatura. É no livro do próprio Kossoy que se encontra um trecho de carta de Florence a Ignacio Betholdi, em que se lê: " $V . S$. sabe que desde 1830 inventei a Polygraphia. (...) O processo da polygraphia foi publicado no Observador, na Phenix, em 1836, mas todos estes esforços não deixavão mais rastos no publico que huma pedra que cabe n'hum tanque". Apud Boris Kossoy (2006, p. 146). (Itálico nosso). Vale destacar aqui por que é importante reconstituir o histórico dessa nomenclatura. Na medida em que o nome implica uma diferenciação de técnicas e métodos, ele auxilia na elaboração de uma cronologia mais precisa das 
invenções e evidencia as relações de parentesco entre elas.

42. "Cette découverte aura des avantages indicibles. L'appareil s'y trouve réduit à un carreau de vitre: les ingrédients à une dissolution de nitrate d'argent".

43. "Mais ce qui devait être obscur, était clair, ce qui devait être clair, était obscur".

44. Colocado aqui entre aspas, pois essa expressão não consta no diário de Florence. A noção de "negativo/positivo" na fotografia começou a ser aplicada a partir das experiências de William Fox Talbot (1800-1877), mas o nome de batismo é atribuído a John Frederick William Herschel (1792-1871).

45. "En effet, si j'ai pu fixer une fois l'image d'une fenêtre sur le papier à plus forte raison je pourrai le faire en rendant bien lumineuse la figure de la personne qui veut avoir son portrait". Hercule Florence, Livre d'annotations..., p. 134.

46. Florence percebeu a relação invertida entre $o$ claro/escuro da imagem natural e o claro/escuro da imagem formada no interior da câmara obscura como um defeito, uma imperfeição do método, e não como resultado de um princípio ótico. A fotografia de Florence consistiu em transferir uma imagem desenhada em uma chapa de vidro para uma folha de papel, pedaço de tecido, superfície de madeira, etc., sob efeito da luz solar.

47. "On pourra observer qu'il est impossible qu'une personne reste assez longtemps". [Poderemos observar que é impossível a uma pessoa permaneça parada por tanto tempo]. Cf. Hercule Florence, Livre d'annotations..., p. $134 \mathrm{v}$. formarem-se no papel as letras escritas na telha. Imediatamente lavou o nitrato de prata e deixou o papel diretamente sob o sol por uma hora. Assim, a parte escurecida pela ação da luz ficou evidente e fundo sob as letras ligeiramente sombreado, permitindo distinguir a frase com clareza. Aqui, Florence regozija-se pelo baixo custo, simplicidade e eficácia do método:

Esta descoberta trará vantagens extraordinárias. $\bigcirc$ aparelho foi aí reduzido a um quadrado de vidro: os ingredientes a uma solução de nitrato de prata ${ }^{42}$.

Para uma terceira experiência, no dia 20 de janeiro de 1833, Florence aprimorou sua câmara obscura. Ao fundo, fixou um pedaço de papel embebido em uma fraca solução de nitrato de prata. À frente, a lente retirada do monóculo. Deixou a câmara mirada para a janela da casa, cujo interior encontrava-se fracamente iluminado pela luz do dia. Após quatro horas, retirou o papel e viu que ali se formara a imagem da janela. "Mas o que deveria estar escuro, estava claro, o que deveria estar claro, estava escuro"43. Florence lavou o nitrato de prata com receio de que ele escurecesse a imagem, sob o efeito da luz do dia. Observou que a parte escurecida nada perdeu de sua intensidade. Deixou, então, o papel sob o sol por uma hora, ao fim da qual a parte clara (blanc) havia escurecido um pouco, mas não o suficiente para deformar o desenho da janela. Nessa experiência, formara-se, pois, a imagem invertida da janela, ou seja, o "negativo"44 da fotografia.

Ainda em janeiro de 1833, numa experiência apenas imaginada, Florence aventou a possibilidade de imprimir pela ação da luz o retrato de uma pessoa:

Com efeito, se pude fixar a imagem de uma janela sobre o papel, estou convencido de que eu poderia fazê-lo deixando bem iluminado o rosto da pessoa que quer obter seu retrato ${ }^{45}$.

Para tanto, seria necessário fundir o procedimento utilizado com a telha de vidro com o da câmara obscura. Um negativo do retrato seria capturado, dentro da câmara, pelo vidro embebido em nitrato de prata. Em seguida, esse negativo fixado no vidro seria lavado e colocado sobre um papel, com nitrato de prata, no qual se poderia ver impressa pela luz a imagem do retratado em positivo. Florence conjectura a possibilidade de atingir a perfeição no processo negativo/positivo ${ }^{46}$. Porém, desconfia da viabilidade do método, prenunciando em 1833, um dos maiores desafios enfrentados pela fotografia no século XIX, qual seja, o longo tempo de exposição necessário à formação da imagem na chapa ${ }^{47}$.

Após a experiência do "claro-escuro", Florence prosseguiu sua pesquisa. Com o auxílio do boticário Joaquim Correia de Melo (1 81 6-1 877), estudou com afinco as obras de Antoine François de Fourcroy (1755-1 809), Jöns Jacob Berzelius (1779-1848), Claude Berthollet (1748-1822) e outros importantes químicos seus contemporâneos. Ensaiou diversos experimentos, testando os efeitos das mais 
variadas substâncias, ora sobre o papel, ora sobre o vidro. No dia 8 de abril de 1833, descobriu o uso da amônia como agente fixador. Nesse dia, expôs ao sol um papel de carta embebido em cloreto de ouro, cobrindo uma das partes com um corpo opaco a fim de impedir o contato com a luz. $\bigcirc$ cloreto de ouro na parte descoberta reagiv escurecendo o papel. A parte encoberta do papel permaneceu com sua coloração original. Em seguida, mergulhou por quinze minutos o mesmo papel num recipiente contendo urina. Retornou o papel ao sol e, após algum tempo, percebeu que a parte que ficara protegida da luz, após ser embebida em urina, não sofreu qualquer alteração. Assim Boris Kossoy explica o sucesso da experiência:

Florence conseguia, de forma inusitada, alcançar relativo sucesso nesta experiência em busca de um método para estabilizar o papel que fora sensibilizado com cloreto de ouro. A urina havia, de alguma forma, dissolvido o cloreto não atingido pela luz. Se, por um lado, Florence constatava que a urina se prestava a esta função, por outro, podemos inferir que o pesquisador tinha conhecimento de que o amoníaco (parte da composição da urina) era o componente fundamental ${ }^{48}$.

Ler o Livre d'annotations et de premiers matériaux na ordem em que foi escrito possibilita entender que, antes de batizar e, por assim dizer, diferenciar os métodos da fotografia e da poligrafia, Florence experimentou técnicas, químicos e uma gama variada de materiais. Tentou imprimir pela luz sobre tecido, vidro, papel e madeira. Os dias 29 e 30 de junho de 1833 testemunharam casos particulares em suas reflexões. No dia 29, nosso inventor imaginou substituir a placa de cera - utilizada na autografia como molde de impressão - por uma placa de cobre. No dia seguinte, conjetura novo experimento: formar uma placa-matriz ${ }^{49}$ de impressão sensibilizada com nitrato de prata. Sobre ela, colocaria uma placa de vidro escurecida por uma mistura de fuligem e goma arábica, na qual seria gravado o desenho. $\bigcirc$ conjunto seria exposto ao sol de modo que a luz atravessasse o desenho da placa de vidro e o projetasse sobre a placa de cobre. Florence imaginou que, após a lavagem da placa-matriz, o nitrato de prata enegrecido pela luz formaria um relevo capaz de servir à impressão.

Alguns desses experimentos permaneceram apenas na imaginação do inventor, mas suscitam uma hipótese: a diversidade de métodos e de instrumentos manipulados por Florence subsidiou a busca por técnicas de impressão eficazes e de baixo custo, denunciando uma confluência, um sentido único nas pesquisas então empreendidas. Inserir-se no universo da revolução gráfica em curso no Ocidente, no contexto de uma economia agrário-exportadora, impunha ao inventor a necessidade de explorar amplamente as condições materiais que se anunciavam, com frequência, como um obstáculo a ser superado. Dessa perspectiva, a fotografia é tributária da autografia e da poligrafia, que podem ser entendidas como evoluções de uma pesquisa orientada para o aprimoramento e, vale frisar, barateamento das técnicas de impressão.

É possível, pela leitura de suas anotações de pesquisa, que Florence como sói ocorrer a outros inventores - não soubesse quais resultados obteria com
48. Cf. Boris Kossoy (2006, p. 192).

49. Florence não menciona o material utilizado na composição dessa "placa", mas refere-se a ele como sendo um "corpo". 
50. "Le 3. Juillet. Plût à Dieu que l'on pût imprimer à la lumière, en obtenant les exemplaires coloriés! Plût à Dieu que l'on trouvât les moyens de fixer les couleurs des objets réfléchis dans la chambre obscure, sur le papier qu'on y placerait, et qu'en faisant un dessin colorié sur le verre ou sur un papier brun transparent, on pût obtenir les exemplaires coloriés! La lumière du soleil et des bougies acquiert la couleur des corps transparents qu'elle traverse, $\mathrm{n}$ n'existe t'il pas un corps, ou ne pourrait-on pas en composer un qui eût la propriété de contracter la couleur des rayons coloriés?"

51. “avec la différence qu'il est plus prompt et facile, et qu'on travaille aussi librement qu'à la plume, sans tourner la planche ni la main, car on sent bien qu'il est plus facile de graver sur une simple couche de noir légèrement gommée, que sur du cuivre". Cf. Hercule Florence, L'ami des arts..., p. 45. suas experiências, mas tinha clareza de seus objetivos. Assim, à medida que o inventor identifica uma técnica com características singulares, ele a batiza com um nome para diferenciá-la dos demais inventos. $\bigcirc$ modo como Florence constrói essa nomenclatura, não raro provisória, permite evidenciar as proximidades entre as diferentes técnicas. No dia 22 de julho, por exemplo, registra no diário o termo poliautografia, uma nomenclatura transitória para o método inacabado da poligrafia. Ora, nas páginas de seu diário, Florence registrou hipóteses e possibilidades de fusão de diferentes técnicas, e uma leitura desses manuscritos guiada somente pelo interesse nos resultados finais das investigações tende a obscurecer outras possibilidades de pesquisa que se apresentaram no horizonte do inventor. Numa de suas digressões, por exemplo, Florence lançou a hipótese de fundir a técnica de impressão pela luz com a da impressão simultânea de várias cores - aliando a fotografia à poligrafia; isso foi registrado no dia 3 de julho de 1833. Essa relação de vizinhança entre as técnicas e os sucessos que Florence buscava alcançar com as pesquisas iniciadas em 1830 foi testemunhada no texto a seguir:

3 de julho. Quisera Deus pudéssemos imprimir à luz, obtendo exemplares coloridos! Quisera Deus encontrássemos meios de fixar as cores dos objetos refletidos na câmara obscura, sobre o papel que ali colocaríamos, e que ao fazer um desenho colorido sobre o vidro ou sobre o papel transparente, pudéssemos obter exemplares coloridos! A luz do sol e das velas adquire a cor dos corpos transparentes que ela atravessa, não existe um corpo ou não poderíamos compor um que possua a propriedade de reter a cor dos raios coloridos? 50.

A explicação do método da fotografia, ou da impressão pela ação da luz solar, aparece melhor acabada no manuscrito L'ami des arts, à página 42. Ali, Florence descreve o aparelho, os materiais empregados e seus procedimentos básicos. $\bigcirc$ aparelho fotográfico se resume a cinco ou seis placas de vidro, variando conforme o numero de cópias que se deseja imprimir. Deve-se ter à mão: uma substância fotossensível (nitrato de prata, cloreto de prata ou, de preferência, cloreto de ouro), fuligem, goma arábica e alvaiade. Após lavar a(s) placa(s) de vidro, devese aplicar sobre ela(s) uma camada da mistura de goma arábica com fuligem. A camada deve ser espessa o suficiente para escurecer a placa, permitindo visualizar através dela apenas a sombra dos objetos. Em seguida, sobre a placa escurecida, despeja-se o alvaiade para formar a base onde será traçado o desenho. Para traçar o desenho na placa, deve-se fazê-lo primeiro em um papel transparente. Em seguida, no sentido inverso, marcam-se os traços do desenho sobre a placa, do lado em que aplicou a camada de fuligem, goma e alvaiade. Com um punção ou buril, reforçamse os traços do desenho na placa, em procedimento comparável ao adotado pelos gravadores sobre uma placa de cobre, "com a diferença que é mais rápido e fácil, e que se trabalha tão livremente como com uma pluma, sem virar a placa nem a mão, pois sentimos que é mais fácil gravar sobre uma simples camada de fuligem levemente engomada, do que sobre o cobre" ${ }^{\prime \prime}$.

Até aqui, com exceção do vidro, Florence utilizou os mesmos instrumentos aplicados na autografia. No lugar da placa-matriz feita em cera, ele simplificou o 
processo, aplicando o desenho sobre o vidro. A diferença estava no processo de impressão, realizado pela ação da luz e não por uma prensa.

Conforme o desenho apresentado a seguir (Figura 17), deve-se colocar apoiado ao chão um pequeno púlpito pintado de preto e inclinado o suficiente para permitir que os raios solares incidam perpendicularmente sobre sua superfície.

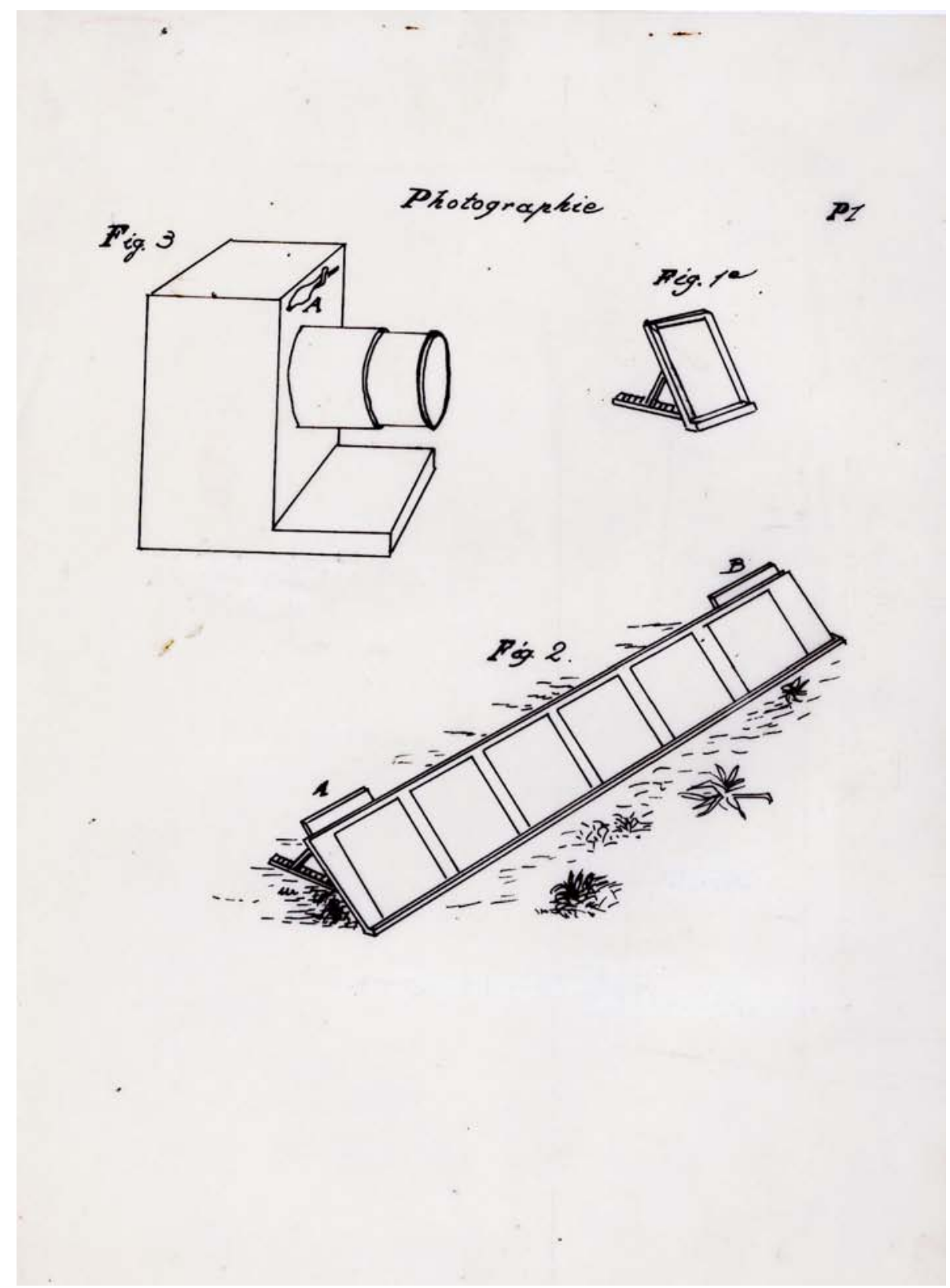

Figura 18 - Photographie. Cópia desenhada por Arnaldo Machado Florence, a partir do original de Hercule Florence. Coleção AMF/Acervo IHF. ( ) Instituto Hercule Florence; Fotografia de Heitor Florence. 
A placa de vidro deve ser colocada sobre o pequeno púlpito, com a face gravada com o desenho virada pra baixo. Uma folha de papel embebida em cloreto de ouro deve ser disposta entre a placa de vidro e a superfície do pequeno púlpito. Após quinze minutos o desenho estará impresso no papel, mas com pouca nitidez. Deve-se, então, levar o papel para um ambiente escuro e colocá-lo numa bacia contendo água e urina. Nessa solução, a amônia agirá fixando a imagem no papel e a água dissolverá o cloreto de ouro, impedindo que este escureça o papel quando em contato com a luz solar. Dessas experiências com a fotografia, sobreviveram apenas exemplares de rótulos de farmácia e diplomas maçônicos impressos por Florence nos anos 1830 (Figura 19).

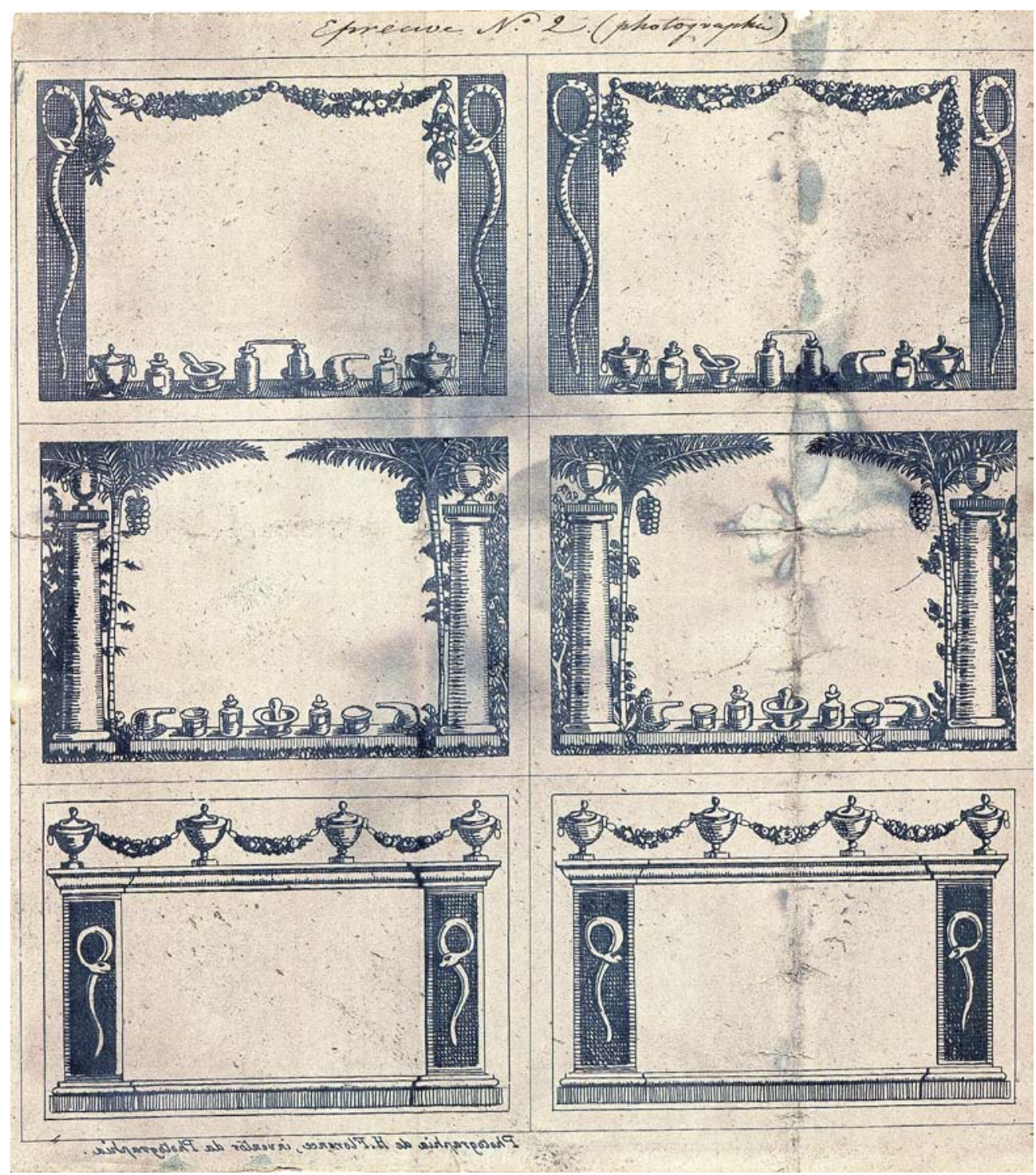

Figura 19 - Fotografia. Conjunto de rótulos para frascos farmacêuticos. Vila de São Carlos (Campinas), SP 1833. Acervo IMS/RJ. Código: 014 IMS 32. 
Segundo o procedimento descrito acima, percebe-se grande semelhança entre o processo da fotografia e o da autografia, pois ambos produzem uma matriz a partir da qual se pode obter cópias impressas. Entretanto, no lugar de imprimir imagens através da ação da tinta no papel, Florence inovou na descoberta dos efeitos da luz solar sobre um agente químico - o cloreto de ouro ou o nitrato de prata. No dia 26 de agosto de 1833, o inventor relatou em seu Livre d'annotations et de premiers matériaux que havia descoberto um "novo procedimento autográfico". A frase foi rasurada e substituída por esta:

De uma nova maneira de multiplicar os escritos e os desenhos, na qual se imprime em talhodoce, sem a necessidade de pressão nem de pranchas de cobre ou de madeira, nem de pedras litográficas, enfim, nada do que se usa nas artes da impressão conhecidas até hoje $e^{52}$.

Nesse dia Florence ainda não havia batizado a nova arte de impressão. Isso explica a incerteza em caracterizá-la como novo procedimento autográfico. $\bigcirc$ verbo photographier, utilizado de modo pioneiro na história ${ }^{53}$, só aparece na página 156, manuscrita em 21 de janeiro de 1834.

Os obstáculos que buscava superar estimularam as experiências e o sucesso na invenção do novo método de impressão. A técnica dispensava a seu usuário a necessidade de uso da prensa, de placas de cobre ou de madeira, de pedras litográficas e de tintas de impressão, que, além de caras, tinham que ser compradas no exterior ou no Rio de Janeiro. A fotografia inventada por Florence, contudo, também tinha suas limitações. $\bigcirc$ uso do cloreto de ouro, bem mais caro que o nitrato de prata ou o cloreto de prata, implicava um custo muito alto, uma vez que todo o papel de impressão deveria ser embebido nessa substância. Florence menciona no L'ami des arts que cada meia página saía a um custo de 60 réis. Para reduzir os custos, sugeriu utilizar o papel de carta, menos absorvente que o papel de imprensa.

Se o Brasil, hoje, tem lugar de destaque na história da fotografia no século XIX, isso se deve a dois motivos. Primeiro, pelo papel desempenhado por Hercule Florence na invenção da fotografia. Segundo, pelo grande interesse do Imperador D. Pedro II no desenvolvimento dessa técnica. Coroado em 1841, D. Pedro II mandou adquirir um daguerreótipo igual ao que o abade francês Louis Compte utilizou para registrar uma imagem do Largo do Paço do Rio de Janeiro, no dia 17 de janeiro de 1840. Logo o Imperador se tornaria grande mecenas e amador praticante da nova arte. Patrocinou a atividade de diversos fotógrafos, subvencionando alguns profissionais por meio da graça conferida pelo título de "Fotógrafo da Casa Imperial". Isso não só possibilitou o aprimoramento da arte e sua difusão em território nacional, mas também impulsionou o intercâmbio tecnológico com outras nações.
52. "D'une nouvelle manière de multiplier les écrits et les dessins, dans laquelle on imprime en taille douce, sans qu'il soit besoin de presse, ni de planches de en cuivre ou de en bois, ni de pierres lithographiques, et enfin, rien de tout ce qui est en usage dans tous les arts d'imprimerie que l'on connaît jusqu'à ce jour". Cf. Hercule Florence, (18301835, p.150).

53. Até a divulgação dos resultados da pesquisa de Boris Kossoy, acreditava-se que a paternidade sobre o termo "fotografia" era do inglês John Frederick William Herschel (17921871), que o teria utilizado em 1839. Cf. Boris Kossoy (2006); Sergio Burgi (2005); Gilberto Ferrez e Weston Naef (1976); Pedro Vasquez (2003). 
54. Cf. Karen Lisboa (2011, p. 35).

55. Georges-Louis Leclerc, conde de Buffon (17071788), autor de Histoire Naturelle, obra em trinta e seis volumes em que analisa os reinos animal, vegetal e humano, sob um ponto de vista comparativo. Para Karen M. Lisboa, as imagens buffonianas da natureza e do homem tropical estabelecem uma dicotomia entre o Velho e o Novo Mundo a partir de critérios da história natural. O tempo e a ação humana interferem pouco nessa reconstrução. A "América emerge como solo infortunado para a vida. (...) o homem selvagem é considerado primus inter pares dos animais, marcado pela debilidade física, pelo tamanho insignificante, pela falta de barba, pela insensibilidade, pela carência de vivacidade - e pelo que mais o depreciaria: sua frigidez sexual". Cf. Karen Lisboa (1997, p 78).

56. Cornelius Franciscus de Pauw (1739-1799), abade holandês, colaborou escrevendo artigos para a Encyclopédie, dirigida por Denis Diderot e Jean D'Alembert. Autor de Recherches Philosophiques sur les Américains, ou Mémoires intéressants pour servir à l'Histoire de l'Espèce Humaine, de Pauw negou qualquer possibilidade de progresso para os americanos. "Além de possuírem menos sensibilidade, menos humanidade, menos gosto, menos instinto, menos coração e menos inteligência, são fisicamente tão frágeis que qualquer europeu, mesmo o mais fraco, derruba-os sem esforço algum”. Cf. Karen Lisboa (1997, p. 79).

57. Ver Mario Carelli (1995, p. 104).
As narrativas da Viagem fluvial

Na passagem do século XVIII ao XIX, a construção da imagem do outro, em particular aquela da natureza e dos habitantes do Novo Mundo, sofria uma profunda mudança. Aos poucos ganhava leitores e espaço nas academias europeias uma "literatura que se afasta do mítico, do fantasioso e do maravilhoso dos tempos precedentes motivada pelo desejo do saber enciclopedista, sistêmico, metódico e racionalista" ${ }^{4}$. Nesse ínterim, a obra de Alexander Von Humboldt consolidaria para quase todo o século XIX um estilo estético-científico na descrição da natureza americana. Contrário às visões depreciativas da natureza e do homem americano, difundidas pelo conde de Buffon ${ }^{55}$ ou por Cornelius de Pauw ${ }^{56}$, Humboldt destaca as relações de interdependência do Novo com o Velho Mundo e desvela um rico manancial para a pesquisa naturalista. Patrocinados por academias de ciência ou por impérios interessados em conhecer o potencial econômico da jovem nação, botânicos, zoólogos, astrônomos, médicos e artistas foram acolhidos no território brasileiro, a fim de identificar, classificar e comercializar registros sobre a fauna e a flora, seus rios, suas vilas e cidades, sua organização social e política, os nativos americanos e os cativos africanos.

Em sua viagem pelo interior do Império do Brasil, entre 1825 e 1829, Hercule Florence preencheu 238 páginas com anotações detalhadas acerca da expedição científica chefiada por Georg Heinrich von Langsdorff (1774-1852), sob patrocínio do Império Russo. Nessas anotações, Florence deixa evidente o seu encantamento com a natureza tropical e suas impressões acerca do encontro com - outro. Seguindo a tradição das narrativas de viagem pelo Novo Mundo, aparecem descrições da fauna e da flora nativas, das diferentes etnias indígenas, de africanos escravizados, de homens livres, capitães de milícia, fazendeiros, governadores, guias e caçadores. $\bigcirc$ Novo Mundo que se abria ao jovem viajante, sob o olhar orientado pelo Barão de Langsdorff, ganhou uma descrição simples, por vezes ligeira, mas direta nas páginas do manuscrito Viagem ao interior do Brasil, feita pelo subscrito, na qualidade de Desenhista do Sr. Cavalheiro Langsdorff, Naturalista e Cônsul-Geral da Rússia no Brasil, Anos 1825-1826-1827-1828 e 182957. A partir dessa matriz textual redigida durante a viagem, Florence compôs outras versões. Como apresentado a seguir, a evolução das pesquisas nesse campo permite estabelecer os contextos de produção e a datação das diferentes versões da narrativa da expedição. Ao final, anexou-se uma tabela com as indicações de datas, títulos e características físicas dos manuscritos que correspondem às diferentes versões da narrativa de Florence.

A expedição partiu por via fluvial de Porto Feliz no mês de junho de 1826; navegou pelo Rio Tietê em direção ao Rio Paraná, alcançado após 53 dias. A 18 de agosto chegou ao Rio Pardo, de navegação penosa até a cabeceira. Para vencer esse trecho com os batelões, pode-se levar até dois meses. Por outro lado, a descida é rápida e não leva mais do que sete dias. Dos primeiros dias de outubro até 21 de novembro a expedição fez pouso na Fazenda 
Camapuam, aonde se chega navegando por afluente homônimo do Rio Paraguai. Partindo daí, se ultrapassam os últimos grandes obstáculos que separam os viajantes da Villa de Cuyabá: as quedas d'água do Rio Coxim e do Rio Taquari, cuja famosa cachoeira Beliago se transpõe com saraivadas de mosquetão, já em clima de festa: "nossos camaradas deram tiros de fuzil, cantaram e gritaram de alegria, pois navegaríamos somente por rios agradáveis" 58 . $\bigcirc$ curso do Rio Paraguai não foi tão fácil quanto se esperava, pois já começara o ciclo das águas e a cheia do rio dificultava o trabalho das zingas. Os terrenos alagados da Laguna de los Xarayes ${ }^{59}$ formam canais pelos quais se perdem os viajantes desatentos. Nessa altura, a expedição entrou em contato com índios Guanás e Guatós. Já era Ano Novo quando os viajantes transpuseram as águas do Rio São Lourenço ao encontro do Rio Cuiabá. No dia 30 de janeiro chegaram ao porto de Cuiabá, após sete meses e meio de viagem, 530 léguas percorridas e 114 cachoeiras vencidas. Bem recebidos e alojados pelo Presidente da Província, José Saturnino da Costa Pereira, os membros da expedição se dividiram em grupos a fim de percorrerem as regiões próximas à capital da Província de Mato-Grosso. Florence juntou-se ao astrônomo Nestor Rubzoff (1799-1874) e Aimé Adrien Taunay (1 803-1828), e seguiu acompanhado por Ludwig Riedel (1791-1861)60. As principais localidades visitadas foram: Vila de Guimarães e Vila Maria, respectivamente, nos dias 28 de abril e 26 de agosto. Ainda a partir de Cuiabá os viajantes remeteram cartas e materiais produzidos até aquele ponto da viagem ao cônsul da Rússia no Rio de Janeiro.

No dia 05 de dezembro de 1827, partiram de Cuiabá sob a orientação de Langsdorff para seguirem na direção das Guianas. Taunay e Riedel seguiriam caminho mais a oeste, com destino a Vila Bela de Mato Grosso, de onde navegariam pelos rios Guaporé, Mamoré, Madeira e Amazonas até a Vila de Santarém, onde se encontrariam com o grupo de Langsdorff. Este, na companhia de Florence e Rubzoff, desceria os rios Preto, Arinos, Jurvena e Tapajoz. Durante essa viagem a tragédia sacrificaria os dois grupos, arruinando os planos mais ambiciosos da expedição: Taunay morreu afogado nas águas do Rio Guaporé e Langsdorff, Rubzoff e Florence sofreram com os males da febre intermitente, a malária. Menos flagelado pela doença, Florence pôde descrever com clareza o contato com os índios Apiacás e Mundurukus. A expedição chegou a Santarém no dia primeiro de julho de 1828 e, no dia 16 de setembro, já aportava em Belém. Riedel, "magro e abatido", alcançou o grupo principal apenas em janeiro de 1829.

Entre os meses de janeiro e fevereiro de 1829, os viajantes zarparam de Belém e navegaram pela costa brasileira rumo à Capital do Império, o Rio de Janeiro. Durante os quarenta dias da turbulenta viagem marítima, Florence começou a passar a limpo seu diário de campo, dando clareza e coesão às anotações. Preencheu 84 folhas $^{61}$ sobre o período de 3 de setembro de 1825 a abril de 1827, narrando desde sua partida do Rio de Janeiro para Santos até a chegada em Cuiabá. Esse manuscrito foi concluído em meados de 1829, no Rio de Janeiro,
58. Hercule Florence, (1830-1835, p. 265).

59. Ver Maria de Fátima Costa (2007, p. 21-36).

60. Em lista expedida no dia 29 de agosto de 1825 , pelo vice-cônsul da Rússia, são apresentados os seguintes participantes com suas respectivas funções: "Nestor Rubzof, astrônomo; Adrian Taunay, Pintor; Hercule Florence, Geógrafo; Luis Riedel, Botânico; Frederico Hasse, Naturalista; os pretos: João Moçambique, Alexandre Cabinda, Antonio Cassange, Pedro Cabinda, Jorge Congo, Antonio Cabinda e o mulato: Jozé Alfaiate”. Cf. Hans Becher (1990).

61. Cf. Ver Affonso Taunay (1948, p. XX). No arquivo do Instituto Histórico e Geográfico Brasileiro (IHGB) encontramos uma parte do manuscrito de Visconde de Taunay, contendo a tradução do diário de Florence. Na testada desse documento está escrito Esboço da viagem feita pelo Snr. Langsdorff no interior do Brasil desde setembro de 1825 até março de 1829. 
62. Essa segunda parte recebera o seguinte título provisório: Continuation de l'esquisse du Voyage de $M$. de Langsdorff dans l'interieure du Brésil depuis $7^{\text {bre }} 1825$ jusqu'em Mars 1829. Parle $2^{\text {eme }}$ Dessinateur de ce Voyage Hercule Florence. Livre Deuxième [Continuação do esboço da viagem do Sr. Langsdorff no interior do Brasil de setembro de 1825 até março de 1829. Pelo segundo desenhista da viagem Hercule Florence. Livro Segundo]. Cf: D. Bertels; Boris Komissarov e Tamara Licenko (orgs) (1988, p. 62).

63. Cf. Boris Komissarov (1994, p. 32).

64. Cf. Affonso Taunay (1948, p. 18).

65. Cf. D.Bertels; Boris Komissarove Tamara Licenko (orgs.) (1988, p. 62).

66. O manuscrito completo consultado na elaboração deste texto está sob a guarda do Instituto Hercule Florence (IHF), em São Paulo. Informações em: www.ihf19.org.br. e, por circunstâncias ainda não esclarecidas, ficou sob a guarda da família de Adrien Taunay. A continuação da narrativa, referente ao período de abril de 1827 a março de 182962, também recebeu uma versão corrigida pelo autor. $\bigcirc$ manuscrito de 70 páginas, concluído na Província de São Paulo, para a qual Florence se mudara em 1830, foi encomendado por Georg Heinrich von Langsdorff (1774-1852), que, enfermo, temia deixar lacunas em seus próprios relatos. A partir da correspondência de Florence citada pelo historiador Boris Komissarov ${ }^{\circ 3}$, sabe-se que Florence entregou o manuscrito a Frans Borel - ministro plenipotenciário russo no Rio de Janeiro - que, por sua vez, o remeteu à Academia de Ciências de São Petersburgo.

As 84 folhas que permaneceram com a família Taunay foram intituladas Esboço da viagem do Sr. Langsdorff no interior do Brasil pelo $2^{\circ}$ desenhista da comissão scientifica Hercules Florence ${ }^{64}$. Título meramente descritivo, provisório, para um documento visto por seu autor apenas como um "esboço", sem intenções editoriais. $\bigcirc$ segundo escrito, enviado à Rússia, recebera um título igualmente provisório: Continuação do esboço da viagem do Sr. Langsdorff no interior do Brasil, de setembro de 1825 até março de 1829, pelo segundo desenhista dessa viagem Hercule Florence. Livro segundo65. Vale dizer que o uso do termo "Continuação", no título, pode significar tanto a sequência do texto entregue à família Taunay quanto um complemento aos manuscritos de Langsdorff. Boris Komissarov considera esses dois manuscritos de Florence como componentes de uma "primeira variante" de suas narrativas da expedição. Porém, não há indícios claros da existência de nexos de continuidade entre eles. Para atestar a existência desses nexos, é necessário ter em mãos as 84 folhas entregues à família Taunay, das quais não se conhece a localização desde que o Visconde de Taunay as encontrou nos anos 1870 .

Depois de muitos anos intocada, a narrativa da expedição só foi retomada por Florence durante a preparação do L'ami des arts. Iniciada em 1837, a redação do manuscrito de 423 páginas foi concluída somente em 1859 após várias interrupções, inclusive, durante a participação de seu autor na Revolução Liberal de 1842. Nesse ano, Florence instalou uma tipografia em Sorocaba para imprimir $\bigcirc$ Paulista, jornal revolucionário de Antonio Diogo Feijó (1784-1843). Igualmente difíceis foram os anos 1846 e 1849, quando Florence enfrentou as dificuldades advindas dos falecimentos de seu sogro e sua esposa, Maria Angélica Álvares Machado e Vasconcellos Florence. Em 1855, mais uma interrupção afastou o autor de seu manuscrito e, dessa vez, também do Brasil: pela primeira vez desde sua chegada à América, Florence retornou à Mônaco para rever a família. De regresso, transferiu-se com a nova esposa - Carolina Krug - para a Fazenda Soledad, no interior paulista. Em meio aos afazeres familiares e a empresa de café, Florence concluiria a redação do L'ami des arts.

A narrativa da expedição, como o leitor pode averiguarob, ocupa 226 das 423 páginas do manuscrito. Ao longo do texto, vários indícios permitem traçar a cronologia de sua composição. Por exemplo, quando descreve a 
chegada da expedição Langsdorff a São Carlos, Florence anotou ter conhecido aquela vila 23 anos antes e que nela habitava há dezoito ${ }^{67}$. Considerando que ele chegara a São Carlos em 1825 e se mudara para a vila em 1831, concluise que a redação do texto foi iniciada em 1849. Quando relata acontecimentos ocorridos em agosto de 1826, Florence recorda ter 22 anos de residência no Brasil68, o que permite datar esse trecho de 1852. Ao descrever o modo de vida dos habitantes que encontrou em Cuiabá no mês de abril de 1827, o autor menciona estar vivendo em Campinas há $23 \operatorname{anos}^{69}$. A escrita se dá, portanto, em 1853. Em 1855, escreveu sobre a Fazenda Jacobina (atual Cáceres - MT)70, onde esteve em setembro de 1827 . Finalmente, quase nas últimas páginas, ele compara o preço da borracha ao de 1828, indicando que já corria o ano de $1859^{71}$.

O capítulo do L'ami des arts dedicado à Expedição Langsdorff foi batizado de Viagem fluvial do Tietê ao Amazonas, pelas províncias brasileiras de São Paulo, Mato Grosso e Grão-Pará e é a única narrativa da viagem em que todo o percurso é relatado em um só manuscrito, em texto coerente e coeso, com destino à publicação. Vale lembrar que a matriz textual utilizada para a composição dessa Viagem fluvial foi a mesma utilizada para a redação das 84 folhas entregues à família Taunay e das 70 páginas enviadas à Rússia por Frans Borel, referentes ao diário levado a campo pelo viajante. Entretanto, diferente desses dois textos produzidos no calor da hora, a redação de Viagem fluvial foi iniciada vinte anos após o término da expedição. Um exercício comparativo, fora dos limites desta apresentação, pode revelar diferenças substanciais entre os textos. Apenas em caráter provisório e na forma de hipótese, pode-se afirmar que os textos produzidos entre 1829 e 1830 são cópias do diário de campo escrito sob as agruras do sertão, enquanto o texto produzido entre 1849 e 1859 é uma narrativa construída segundo parâmetros da literatura de viagem da época, em particular sintonia com as obras que tiveram notória repercussão entre os leitores brasileiros. Vale ainda lembrar que os textos de 1829-1830 foram escritos para atender a uma exigência do líder da expedição, e o de 1849-1859 foi uma produção autoral.

Sob a pena de Florence, além da narrativa sequencial dos episódios envolvendo os membros da expedição, e da descrição dos lugares, rios, cachoeiras, vilas e fazendas, em Viagem fluvial o leitor é convidado a refletir sobre a realidade brasileira de um ponto de vista antiescravista e republicano ${ }^{72}$. A narrativa é entrecortada por análises da evolução histórica do Brasil, reproduzidas, em grande parte, por Florence da obra de Ayres de Casal (1754$18211^{73}$. Outros autores são convidados a contribuir para o enriquecimento da narrativa, como os viajantes Spix, Martius, Burchell e Natterer ${ }^{74}$. A poesia também se fez presente na obra, unindo a descrição orientada da paisagem com 0 sentimento da natureza. Ante o relato técnico da passagem pelo salto do Avanhandava, no Rio Tietê, registrado no diário feito em campo ${ }^{75}$, Florence consagra maior expressividade à narrativa em Viagem fluvial.
67. Ver Hercule Florence, (1837-1859, p. 204).

68. Ibidem, p. 239. No manuscrito, Florence distingue claramente a chegada ao Brasil do seu período de residência na Província de São Paulo, desde 1830 , portanto.

69. Ibidem, p. 301.

70. Ibidem, p. 334

71. Ibidem, p. 416

72 Ainda que a natureza híbrida da literatura de viagem, vista como um subgênero literário, imponha certos cuidados na análise de seus parâmetros, todo e qualquer texto que tenha por motivação a viagem pode ser aí enquadrado. Ver Fernando Cristóvão (2002, p. 15). Ainda sobre o tema, Karen Lisboa entende que a se valer de uma ou outra obra, a diversidade de textos abrange "a crônica, a epístola, o romance, a poesia, o diário e o relato científico, acrescentado não raramente do correspondente iconográfico". Cf. Karen Lisboa (1997, p. 34).

73. Ver Manuel Aires de Casal (1817).

74. Cito: Johann Baptist von Spix (1781-1826), Carl Friedrich Philipp von Martius (1794-1868), William John Burchell (1781-1863) e Johann Natterer (1787-1843). Tratam-se de figuras com as quais Florence teve contato no Brasil, das quais os dois primeiros, por sua Viagem ao Brasil, já ganhavam fama internacional. Cf. Pablo Diener e Maria de Fátima Costa (orgs.) (2012) e Karen Lisboa (1997).

75. Aqui o "diário de campo" se refere ao texto traduzido e publicado pelo Visconde de Taunay. 
76. Hercule Florence, (1837-1859, p. 231).

77. Ibidem, p. 233. Texto original: "Il y a au Brésil beaucoup de gens qui prônent l'esclavage comme avantageux pour les esclaves même: c'est pure hypocrisie; je pourrais citer des milliers de cas qui prouvent que les noirs préfèrent s'exposer à tous les périls, à toutes les misères plutôt que de porter patiemment les chaînes dont ils sont rivés par leurs avides tyrans”.

78. Cf. Tâmis Parron (2011).
Em um momento de entusiasmo eu chorei:

\author{
Avanhandáva! ainda vejo e admiro \\ sobre teo amphiteâtro de granito, \\ Hum caudaloso rio transformado, \\ Em toalha tecida, \\ D'alvos brilhares, trémulo-cadentes! \\ Itapura! ainda aos ouvidos soão-me, \\ Com eternos trovões, harpas eólicas, \\ Que vagamente enlevão!?6
}

Na sequência, deixando para trás o salto do Avanhandava, a expedição retoma seu curso. Nesse ponto, Florence suprime o tempo cronológico da narrativa para relatar uma anedota. Conta que, em 1818, uma expedição buscava o caminho de Cuiabá via fluvial quando encontrou uma negra que vivia isolada numa das ilhotas do Rio Tietê. Sob o olhar do viajante, a triste história dessa escrava que fugiu com seu marido da Fazenda Camapuam encerra-se com a trágica morte do companheiro por afogamento e sua devolução aos antigos proprietários. Suspende, então, a narrativa do deslocamento ao sertão para anotar a seguinte digressão:

Existem muitas pessoas no Brasil que advogam ser a escravidão vantajosa para os próprios escravos: isso é pura hipocrisia; eu poderia mencionar milhares de casos que provam que os negros preferem se expor a todos os riscos e à miséria que carregar pacientemente as correntes nas quais foram colocados por seus ávidos tiranos 77 . (Tradução nossa).

Tanto a defesa da escravidão quanto os "milhares de casos" mencionados por Florence integravam boa parte do debate público naqueles anos. As visões acerca da liberdade e da escravidão se vinculavam, de modo inexorável, aos efeitos do processo de abolição do tráfico de africanos escravizados para o Brasil, primeiro pela Lei de 07 de novembro de 1831 e, em num segundo e definitivo momento, pela Lei Eusébio de Queiroz em 1850. Na história do Império do Brasil, as décadas de 1830 e 1840 foram marcadas pela bem-sucedida articulação escravista em torno da continuidade do tráfico. Como demonstra o historiador Tamis Parron78, após um período de contrabando residual entre 1831 e 1834/5, houve uma forte retomada do "infame comércio" na forma de contrabando sistêmico até 1850. Umbilicalmente sustentada pelos políticos do Regresso, essa retomada foi possível graças a uma política do contrabando defendida no parlamento brasileiro e emplacada no bojo da reforma do Ato Adicional de 1834 e da reforma judiciária concluída em 1841. Às ações do poder executivo, uniram-se as representações parlamentares favoráveis ao tráfico e a não punição dos contrabandistas. A defesa da introdução do "braço escravo" sob regime de contrabando, protegida por estruturas basilares do Império, garantiu a introdução de grande volume de africanos: se, por um lado, entre 1831 e 1834, 
ingressaram no território cerca de 40 mil novos africanos ilegalmente escravizados, entre 1836 e 1839, esse número saltaria para a impressionante cifra de 270 mil. Sustentar o tráfico em situação de ilegalidade e de uma intensa pressão britânica para o rompimento das relações comerciais África-Brasil exigiu a construção de uma política institucionalmente sólida e ideologicamente justificada.

É, portanto, digno de nota o trecho do diário, destacado acima, em que Florence critica os que "advogam ser a escravidão vantajosa para os próprios escravos". À sua maneira, o viajante dialogava com as falas em defesa do tráfico e do cativeiro veiculadas nos impressos daquele período. Florence flagrantemente discordava da visão defendida pelo seu sogro Álvares Machado na Câmara dos Deputados do Império em 1840. Voz dissonante na Assembleia da Província de São Paulo, Álvares Machado interviria ali em favor da política do contrabando negreiro encabeçada pelos correligionários do Regresso, afirmando defender "o direito de filantropia e benefício que fazemos aos africanos, tomando-os das mãos bárbaras e cruéis de seus senhores e trazendo-os a um país civilizado e, pelo lado religioso, abrindo-thes as portas do céu, batizando-os e fazendo-os cristãos"79. Leitor de Fourier ${ }^{80}$, Florence se contrapôs aos argumentos pró-escravistas reverberados pelo sogro no parlamento. A crítica, contudo, não foi dirigida nomeadamente a Álvares Machado, mas aos que a "advogam...". Redigido após 1849, quando este já havia falecido, o argumento de Florence poderia ter impacto sobre outro público leitor, sobretudo aquele que viveria na conjuntura histórica marcada pelos efeitos do fim do tráfico de escravos, do fortalecimento da causa abolicionista, da política de substituição dos africanos escravizados por europeus nas lavouras de São Paulo e da defesa do cativeiro pela classe senhorial até o ocaso do Império. Este e outros trechos da narrativa da expedição do L'ami des arts são evidentemente díspares em relação ao texto publicado na Revista do $\mathbb{H G B}^{81}$, citado a seguir, na tradução e edição do Visconde de Taunay. Nem o tom poético assumido na narrativa do encontro com o Avanhandava, nem o tom panfletário do argumento antiescravista aparecem na última versão. Não pairam dúvidas sobre o fato de que o visconde adequaria o texto original ao projeto nacionalista e civilizatório daquela instituição ${ }^{82}$.

Considerando as dificuldades do meio, a dedicação às pesquisas da poligrafia e da fotografia, o tempo dedicado à criação e educação de sua extensa prole, não parece estranho que Florence tenha conseguido publicar sua narrativa da Expedição Langsdorff apenas no último quarto do século XIX, quase cinquenta anos após o fim da viagem. Além das escolhas pessoais e da premência das obrigações da vida familiar, a pesquisa nas suas correspondências ativas revelou outros fatores que desestimularam, por longo período, a preparação do manuscrito para publicação. Já no curso final da expedição, a 10 de novembro de 1828, Florence escreveu do Grão-Pará para sua família, em Mônaco, declarando sua descrença numa possível edição da narrativa pela Academia de Ciências da Rússia $^{83}$. Suas suspeitas eram legítimas e, em carta a Charles Taunay, de $1862^{84}$, Florence declarou que Langsdorff exigiu sua assinatura em um contrato, pelo qual se comprometia a não publicar seu relato antes que o chefe da expedição
79. Anais da Camara dos Deputados, 21 de agosto de 1840, apud Tâmis Parron (2011, p. 127).

80. Com base nos argumentos em defesa do associativismo de FrançoisMarie-Charles Fourier (1773-1835), Florence valoriza a experiência do quilombo como lugar de afirmação da comunidade liberta da escravidão, compartilhando os frutos do trabalho, em comunhão religiosa sem clérigos.

81. O que neste texto segue intitulado Revista do IHGB refere-se à Revista Trimensal do Instituto Histórico, Geográphico e Ethnográfico do Brasil.

82. Ver Sérgio Campos Gonçalves (2010)

83. Boris Komissarov (1994, p. 32-33) informa que esse documento faz parte da coleção Cyrillo Hercules Florence.

84. Correspondência de Hercule Florence a Charles Taunay, "À Monsieur Charles Auguste Taunay, Major au service du Brésil. Rio-de-Janeiro Septembre 1862", em L'inventeur au Brésil..., p. 19. 
85. Ver Paulo Vanzollini (1996).

86. Cf. Roderick Barman (1971, p. 92).

87. Ibidem, p. 92.

88. Correspondência de Hercule Florence a Monsieur Duvignau, Campinas, 14 de dezembro de 1868. L'inventeur au Brésil..., p. 94.

89. Correspondência de Hercule Florence a Philibert Florence, Campinas, 15 de outubro de 1868 . L'inventeur au Brésil..., p. 96. publicasse o dele. Os planos de Langsdorff, porém, não vingaram. As febres intermitentes the deixaram sequelas gravíssimas e, afastado de suas funções científicas, regressou à Freiburg, onde faleceu em 1852 sem publicar seus estudos da expedição. É bastante plausível que, sob a vigência desse contrato, Florence não tenha se esforçado para publicar sua própria narrativa.

A fama da expedição, de fato, não foi marcada pela riqueza, ineditismo nem ampla divulgação do material coletado ${ }^{85}$. Em desfecho ainda pouco estudado pela historiografia, todo o material restou bloqueado pela Academia de Ciências da Rússia, por decisão do Czar Nicolau I. O historiador Roderick Barman defende que "a publicação dos materiais da expedição foi efetivamente bloqueada por conflitos internos à comunidade científica russa"86. A Academia de Ciências não estava oficialmente envolvida com a missão russa no Brasil quando Langsdorff recebeu as primeiras instruções para a realização da expedição, em 1821. Barman diz que a instituição viria a assumir o encargo de receber o material coletado na América apenas com a criação do Jardim Botânico de São Petersburgo em 1823, dirigido por um amigo de Langsdorff, F. B. Fischer, que se consagraria como o responsável pela organização do mais completo jardim botânico conhecido na primeira metade do século XIX. Georg Heinrich Von Langsdorff era, oficialmente, o único autorizado a compilar, classificar, analisar e publicar a grande memória relativa à exploração científica do vasto território do Império do Brasil.

Contudo, a chegada de Nestor Rubtsov à Rússia em 1830 parece ter modificado os planos da academia e, ao tomar ciência do adoecimento do barão no Brasil, "Fischer imediatamente reivindicou não apenas estes [o material levado à Rússia por Rubtsov] mas todos os materiais já recebidos pela Academia e, após longa e complexa disputa, o Czar Nicolau I decidiu a favor de Fischer em março de $1831^{\prime \prime 87}$. A expedição se desmembrara após a chegada ao Rio de Janeiro: Florence se mudou para São Paulo, Rubtsov regressou à Rússia, Langsdorff retornou à Freiburg e Riedel, único membro efetivamente vinculado à Academia após 1829, continuou fazendo coletas no Brasil até 1836. As últimas remessas de material à Rússia ficaram sob a responsabilidade de Riedel, quando muitas já haviam sido desencaminhadas pelos outros membros. De 1836 até a abertura dos arquivos russos nos anos 1930 paira uma incógnita acerca dos usos desse material.

No Brasil, a partir dos anos 1860, encontram-se indícios dos primeiros esforços de Florence para a publicação de seu relato de viagem. $\bigcirc$ primeiro registro encontrado foi na correspondência a Charles Taunay mencionada nos primeiros parágrafos deste texto. Em 1868, por indicação de Taunay, Florence buscou um editor estrangeiro por intermédio do diretor do Institut Duvignau de Paris, onde seu filho Arnaldo estudava. No caderno L'inventeur au Brésil. Correspondance et pièces scientifiques há cópia da correspondência em que Florence manifesta o interesse em publicar "alguns trabalhos aos quais me dedico há quarenta anos" 88 . Entre os trabalhos indicados, aparece o referente à Viagem fluvial, "acompanhado de duzentos desenhos". Por fim, antes mesmo de obter uma resposta, Florence pede a seu sobrinho, Philibert Florence, para ajudá-lo a encontrar um editor na França ou na ltália ${ }^{89}$. 
Curiosamente a Guerra do Paraguai (1 865-1 870) trouxe bons agouros para Florence. Não fosse o conflito talvez ele não tivesse conquistado a admiração do sobrinho de Charles Taunay. Alfredo D'Escragnolle Taunay, com apenas 22 anos, passou por Campinas em marcha para os campos de batalha. Ali, encantouse com as histórias e explicações do inventor sexagenário. Superada a "retirada da Laguna" e os trágicos episódios da invasão do Paraguai, Alfredo Taunay, entrando nos anos 1870, retornou ao Rio de Janeiro e se pôs a revirar antigos papéis da família. Assim, um pouco ao acaso, encontrou as 84 folhas copiadas por Florence durante a viagem de Belém ao Rio de Janeiro, em 1829. Sobre esse documento, Taunay comentou:

O que li sob o título Esboço da viagem do Sr. Langsdorff no interior do Brasil pelo $2^{\circ}$ desenhista da comissão scientifica Hercules Florence, não é senão um seguimento de rápidas notas e apontamentos tomados para receberem, em trabalho completo e regular, todo o desenvolvimento desejável; entretanto n'isso mesmo achei tanto interesse pela singeleza de narrativa, vivacidade de colorido e prudência de apreciação, que o fui traduzindo desde logo com destino às páginas da Revista do Instituto Histórico, a qual sem duvida o receberá com gosto90.

Quando Alfredo Taunay escreveu a Florence contando-the a notícia, este acabara de completar setenta anos. Sem dúvida, a possibilidade de uma publicação na Revista do $\mathbb{H}$ GB foi recebida com grande entusiasmo e reconhecimento de mérito. De sua parte, Florence se prontificou a complementar o material que Taunay já começara a traduzir. Às 84 folhas que abarcavam a narrativa da expedição desde a partida do Rio de Janeiro até a chegada em Cuiabá, Florence acrescentou mais algumas dezenas de páginas, copiadas do manuscrito de Viagem fluvial, este pronto para publicação desde 185991. A primeira publicação apareceu no volume 1 do tomo 38 da Revista do $\mathbb{H G B}$, entre as páginas 355 e 469, o que corresponde à parte da narrativa relativa aos meses de setembro de 1825 e agosto de 1827 . Já no volume 2, do mesmo tomo, aparece a continuação da narrativa entre as páginas 231 e 301, e, finalmente, no volume 2, tomo 39, a conclusão até a chegada ao Rio de Janeiro, entre as páginas 157 e 182

A publicação dessa narrativa da expedição na Revista do IHGB foi, portanto, resultado de trabalho editorial do Visconde de Taunay a partir de textos de Florence escritos em contextos diversos. Além da tradução, Taunay criou subtítulos, excluiu trechos e finalizou o texto em tom, ao mesmo tempo, heroico e trágico:

(...) com 46 dias de bordo alcançávamos a cidade do Rio de Janeiro, dando fim à nossa penosíssima, atribulada e infeliz peregrinação pelo interior do vasto Império do Brasil92.

A duras penas, tal como Taunay o havia feito na frente de batalha, os expedicionários sobreviveram às atribulações da viagem pelo sertão. $\bigcirc$ final redigido por Florence no texto 93 enviado a Taunay sequer menciona o "Império do Brasil", que figura implantado por seu tradutor.
90. Cf. Affonso Taunay (1875, p. 339). Itálico nosso.

91. Ver Affonso Taunay (1948, p. 18).

92. Hercule Florence (1948, p. 218).

93. O arquivo do IHGB-RJ não possui todas as remessas enviadas por Florence a Taunay. Encontramos a que equivale ao quinto e último envio (Lata 350, doc. 28), com a narrativa de setembro de 1828 a março de 1829 , que a comparação provou ser idêntica à parte correspondente no manuscrito do L'ami des arts. A última frase de Florence transmite o alívio de se chegar a um porto seguro: "(...) após 46 dias de travessia, felizmente chegamos ao Rio de Janeiro". Cf. Hercule Florence, (1837-1859, p. 421). 


\section{Tabela 1 - Manuscritos da Viagem fluvial}

\begin{tabular}{|c|c|c|c|}
\hline $\begin{array}{l}\text { Ano(s) de } \\
\text { produção }\end{array}$ & Título & Descrição & Arquivo \\
\hline 1825-1829 & $\begin{array}{l}\text { Viagem ao interior do Brasil, feita } \\
\text { pelo subscrito, na qualidade de } \\
\text { Desenhista do Sr. Cavalheiro } \\
\text { Langsdorff, Naturalista e Cônsul- } \\
\text { Geral da Rússia no Brasil, Anos } \\
\text { 1825-1826-1827-1828 e } \\
\text { 1829. Hercule Florence }\end{array}$ & $\begin{array}{l}238 \text { páginas manuscritas durante a } \\
\text { expedição }\end{array}$ & $\begin{array}{l}\text { Coleção Cyrillo } \\
\text { Hercules Florence, } \\
\text { São Paulo, Brasil. } \\
\text { (Curadora: Leila } \\
\text { Florence de } \\
\text { Moraes) }\end{array}$ \\
\hline 1829 & $\begin{array}{l}\text { Esboço da viagem do Sr. } \\
\text { Langsdorff no interior do Brasil } \\
\text { pelo } 2^{\circ} \text { desenhista da comissão } \\
\text { scientifica Hercules Florence }\end{array}$ & $\begin{array}{l}84 \text { folhas manuscritas frente e verso } \\
\text { durante o regresso da expedição ao } \\
\text { Rio de Janeiro. Seu texto corresponde } \\
\text { ao o período de } 3 \text { de setembro de } \\
1825 \text { a abril de } 1827 \text {, desde o dia da } \\
\text { partida do Rio de Janeiro até a } \\
\text { chegada em Cuiabá. } \\
\text { Ficaram com a Família Taunay no Rio } \\
\text { de Janeiro e, posteriormente, foram } \\
\text { encontradas pelo Visconde de Taunay } \\
\text { em } 1874 \text {. }\end{array}$ & Não há notícias. \\
\hline $1829 / 1830$ & $\begin{array}{l}\text { Continuação do esboço da } \\
\text { viagem do Sr. Langsdorff no } \\
\text { interior do Brasil, de setembro de } \\
1825 \text { até março de 1829, pelo } \\
\text { segundo desenhista dessa } \\
\text { viagem Hercule Florence. Livro } \\
\text { segundo }\end{array}$ & $\begin{array}{l}70 \text { páginas. Manuscrito concluído na } \\
\text { Província de São Paulo em } 1830 \text { a } \\
\text { pedido de Langsdorff. Refere-se ao } \\
\text { período de abril de } 1827 \text { a março de } \\
\text { 1829. Enviado à Rússia por Frans } \\
\text { Borel. }\end{array}$ & $\begin{array}{l}\text { Arquivo da } \\
\text { Academia de } \\
\text { Ciências (Arkhiv } \\
\text { Akademii Nauk), } \\
\text { Moscou, Rússia. } \\
\text { Fundo } 63 \text {, } \\
\text { inventário 1, n. 8, } \\
\text { folhas 1-88. }\end{array}$ \\
\hline 1849-1859 & $\begin{array}{l}\text { Viagem fluvial do Tietê ao } \\
\text { Amazonas, pelas províncias } \\
\text { brasileiras de São Paulo, Mato } \\
\text { Grosso e Grão-Pará }\end{array}$ & $\begin{array}{l}226 \text { páginas. Escritas ao longo de dez } \\
\text { anos, no caderno L'ami des arts livré à } \\
\text { lui-même. }\end{array}$ & $\begin{array}{l}\text { Instituto Hercule } \\
\text { Florence (IHF). São } \\
\text { Paulo, Brasil. }\end{array}$ \\
\hline $1875-1876$ & $\begin{array}{l}\text { Esboço da viagem do Sr. } \\
\text { Langsdorff no interior do Brasil } \\
\text { pelo } 2^{\circ} \text { desenhista da comissão } \\
\text { scientifica Hercules Florence. } \\
\text { Traduzido pelo Visconde de } \\
\text { Taunay }\end{array}$ & $\begin{array}{l}\text { Publicado na Revista Trimensal do } \\
\text { Instituto Histórico, Geographico e } \\
\text { Ethnographico do Brasil, 1875, Vol. 1, } \\
\text { Tomo 38, p. 355-469, Vol.2, p. } 231 \text { - } \\
\text { 301; 1876, Vol.2, Tomo 39, p. 157- } \\
\text { 182. }\end{array}$ & $\begin{array}{l}\text { Instituto Histórico e } \\
\text { G e o g r á f i c o } \\
\text { Brasileiro (IHGB- } \\
\text { RJ), Rio de Janeiro, } \\
\text { Brasil }\end{array}$ \\
\hline
\end{tabular}


Além de editor da primeira publicação da narrativa de Florence ${ }^{94}$, Visconde de Taunay também militou a favor de sua publicação na Europa. É o que se verifica em carta de Florence ao editor do periódico Le Tour du Monde. Nouveau Journal des Voyages, Edouard Thomas Charton (1807-1890), de janeiro de 187695. Nela, Florence diz que o Visconde de Taunay o incentivava a propor a publicação ilustrada da Viagem fluvial, com oitenta desenhos faits sur les lieux. $\bigcirc$ material que ofereceu ao editor francês não é, entretanto, o mesmo publicado por Taunay sob o título de Esboço da viagem.... Conforme explica na missiva, "o que apareceu [na Revista do IHGB] foi o relato escrito nos lugares, enquanto que meu manuscrito atual foi corrigido e aumentado. A digressão à Chapada é da nova redação". Portanto, talvez insatisfeito com as intervenções de Taunay no texto original ou com a compilação de textos não coevos, Florence decidiu enviar à Europa o texto mais acabado do L'ami des arts.

Não há noticia do desfecho da proposta de Florence a Mr. Charton. Pesquisas nos arquivos e periódicos franceses podem trazer à luz novos textos ou referencias à obra de Hercule Florence. Sabe-se apenas que a única publicação de Viagem fluvial na Europa sairia somente em 1913, 34 anos após a morte de seu autor. Editada por Philibert Florence, seu sobrinho, na revista de história do Principado de Mônaco - Monaco Revue ${ }^{96}$-, prenunciava para o século XX o empenho dos descendentes de Florence na preservação e divulgação de sua obra.

Narrando viagens e invenções

A invenção da fotografia no século XIX ocorreu por um conjunto de condições econômicas e culturais específicas. A busca por suas origens, numa leitura historiográfica contemporânea ${ }^{97}$, permite vinculá-la à história das artes gráficas e, assim, compreender a fotografia como etapa, sem dúvida culminante, da evolução das técnicas de impressão de textos e imagens. As invenções de Hercule Florence, no Brasil, e aquelas de Joseph Nicéphore Niépce, Lovis Jacques Mandé Daguerre e William Henry Fox Talbot, na Europa, fazem parte do processo em que a "impressão pela luz" resultou de inúmeras experiências realizadas com métodos e técnicas empregados nas artes gráficas. Embora as condições na periferia do capitalismo industrial não tenham favorecido o reconhecimento de Florence junto às academias europeias nem a evolução rápida de suas pesquisas, o experimentalismo e o empirismo que se destacam nas páginas de suas anotações científicas demonstram que ele esteve alinhado com a ciência praticada no Velho Mundo.

Narrar a própria invenção com um viés autobiográfico, como o fez Florence no L'ami des arts, também constituía uma prática recorrente entre cientistas e inventores dos dois lados do Atlântico. Niépce ${ }^{98}$, Talbot ${ }^{99}$ e Alberto Santos Dumont $^{100}$ registraram igualmente suas descobertas em textos que mesclavam narrativa autobiográfica e relato de invenção. A presença de traços biográficos ou autobiográficos na descrição de processos que redundaram na invenção de novas tecnologias é uma questão ainda pouco estudada. Anne McCauley ${ }^{101}$ assevera
94. Ao contrário do que diz Roderick Barman, o relato de Florence não foi o primeiro a ser publicado sobre a expedição. Antes dele, Johann Moritz Rugendas já havia publicado, em 1825, seu livro Viagem pitoresca através do Brasil, resultado de seu trabalho na equipe de Langsdorff, iniciado em 1822. Ver Roderick Barman, (1971).

95. Correspondência de Hercule Florence a Edouard Thomas Charton, Campinas, 02 de janeiro de 1876. L'inventeur au Brésil..., p. 129.

96. Ver Hercule Frorence (1912). 
97. Ver Joaquim Marçal Andrade (2005, p.60).

98. Série de correspondências e relatos reunidos por Manuel Bonnet e Jean-Louis Marignier (2003). Ou ain$\mathrm{da}$, o livro em que Isidore Niépce narra a invenção do daguerreótipo. Cf. Isidore Niépce (1841).

99. Ver Willam Talbot (1844).

100. http://g1.globo.com/ Noticia s / C i e n cia / 0,,AA1319088-5603,00. html. Acesso em 25 ago 2012

101. Ver Anne Mccauley (1997, p. 88). que a autobiografia satisfaz duas necessidades: por um lado, um desejo de conquistar a imortalidade possível através da escrita e, por outro, a vontade imediata de comunicar a alguém a essência de uma vida. Nos textos de Florence, elementos de sua vida pessoal aparecem com grande frequência, tanto na narrativa das invenções, quanto no relato da Expedição Langsdorff. Referências à sua condição de vida, às dificuldades enfrentadas na criação dos filhos, além de críticas à sociedade escravista da Província de São Paulo, são recorrentes em seus textos. Quase sempre apresentados no início das narrativas - seja das invenções seja das viagens -, esses aspectos da vida do inventor servem para historicizar o processo que resultou na invenção, mas também para estabelecer claramente os horizontes e possibilidades que, por vezes, revelam os obstáculos à evolução das pesquisas. Assim, afora as duas razões apontadas por McCauley, pode-se afirmar que, no caso de Florence, a presença de traços autobiográficos possui ainda uma função legitimadora, na medida em que situa o indivíduo no seu contexło histórico e social.

Se as narrativas de invenção não constituíram um campo de estudos nas ciências humanas, as de viagem já se firmaram há algum tempo, inclusive como gênero literário autônomo. Nessa esfera, Florence marcou seu lugar ao ser o primeiro a publicar o relato integral da viagem fluvial promovida pelo Barão de Langsdorff entre 1825 e 1829. Ainda que seus manuscritos relativos à viagem estejam dispersos por arquivos e coleções, no L'ami des arts Florence fixou uma versão completa da narrativa da expedição. Futuramente, um estudo comparativo dos textos apresentados na tabela acima poderá iluminar diferenças de padrão narrativo (ora mais técnico, ora mais literário), permitindo caracterizar a influência de outros textos na composição do relato (intertextualidade) e, também, compreender as possibilidades de estudo do contexto pelo texto narrativo, em suas diferentes versões. Por fim, é importante assinalar que a contribuição original do L'ami des arts foi reunir, de modo inédito, as viagens e as invenções de um ícone do século XIX. 


\section{REFERÊNCIAS}

\section{MANUSCRITOS}

Acervo Instituto Hercule Florence (IHF), Coleção Arnaldo Machado Florence

FLORENCE, Hercule. L'ami des arts livré à lui-même. Recherche et découvertes sur différents sujets nouveaux, 1837-1859. Coleção Arnaldo Machado Florence, Acervo IHF, São Paulo.

FLORENCE. Hercule. Livre d'annotations et de premiers matériaux, 1830-1835. Coleção Arnaldo Machado Florence, Acervo IHF, São Paulo.

FLORENCE, Hercule. L'inventeur au Brésil. Correspondances et pièces scientifiques. Coleção Arnaldo Machado Florence, Acervo IHF, São Paulo.

Biblioteca Nacional do Rio de Janeiro

FLORENCE, Hercule. Découverte de la polygraphie par Hercule Florence. Campinas, Province de St. Paul, au Brésil, le 1er août 1853. Acervo Iconográfico, BNRJ, Rio de Janeiro.

Instituto Moreira Salles (IMS/RJ)

$1^{e r}$ essai polygraphique, fait en gravant à jour avec la pointe d'un canif, sur un papier tendu. Acervo IMS/RJ. Código: 014Florence01C.

Instituto Histórico e Geográfico Brasileiro (IHGB/RJ)

FLORENCE, Hercule. "Voyage Fluvial du Tiété á l'Amazone"; "Rio de Janeiro"; "Zoophonie

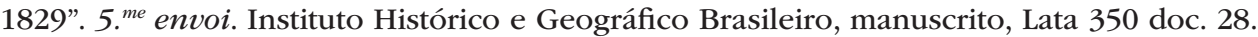

FLORENCE, Hercule. "Zoophonie, continuation"; "L'Inventeur au Brésil - Recherches et Découvertes d'un Européen pendant quarante sept ans de résidence dans l'intérieur de cet Empire - Découverte de la Polygraphie 1830". 6. "me envoi. Instituto Histórico e Geográfico Brasileiro, manuscrito, Lata 350 doc. 28.

\section{ICONOGRAFIA}

Biblioteca Nacional do Rio de Janeiro.

Papel inimitável. Acervo Iconográfico / BNRJ

O Farol Paulistano, 08 de junho de 1830. Disponível em: http://memoria.bn.br/DocReader/ DocReader.aspx?bib=700169\&PagFis=1781. Acesso: em: 25 ago. 2012. 
Instituto Moreira Salles (IMS/RJ)

$2 m e s$ Essais polygraphique, 1830. Acervo IMS/RJ. Código: 014Florence01A

Descuberta da polygraphia. Circular. S. Carlos, 1834, Polygraphia de Hercules Florence. Acervo IMS/RJ. Código: 014Florence04.

Poligrafia. Anúncio em cinco cores da Fábrica de Chapéus São Gonçalo, na Província de Minas Gerais. Campinas, SP, s/d. Acervo IMS/RJ. Código: 014Florence06.

Fotografia. Conjunto de rótulos para frascos farmacêuticos. Vila de São Carlos (Campinas), SP, 1833. Acervo IMS/RJ. Código: 014IMS 32.

\section{LIVROS, ARTIGOS E TESES}

ABRAHÃO, Eliane Morelli. Morar e viver na cidade. Campinas (1850-1900). São Paulo: Alameda, 2010.

ANDRADE, Joaquim Marçal Ferreira de. Do gráfico ao foto-gráfico: a presença da fotografia nos impressos. In.: CARDOSO, Rafael Cardoso (org.) o design brasileiro antes do design: aspectos da história gráfica, 1870-1960. São Paulo: Cosac Naify, 2005.

BARDI, Pietro Maria. Agenda Olivetti 1980: o poliédrico Hercules Florence. São Paulo: [Departamento de Projetos e Publicidade Olivetti do Brasil S.A.], [1979].

BARMAN, Roderick. The Forgotten Journey: Georg Heinrich Langsdorff and the Russian Imperial Scientific Expedition to Brazil, 1821-1829. Terrae Incognitae, n. 3, p 67-96.

BECHER, Hans. O Barão Georg Heinrich von Langsdorff: pesquisas de um cientista alemão no século XIX. Brasília: EdUnB, 1990.

BERTELS, D. E.; KOMISSAROV, Boris Nikolaevich; LICENKO, Tamara.I. (org.). A expedição cientifica de G. I. Langsdorff ao Brasil, 1821-1829: catálogo completo do material existente nos arquivos da União Soviética. Brasília: Secretaria do Patrimônio Histórico e Artístico Nacional / Fundação pró-Memória, 1988.

BOURROUL, Estevam Leão. Hercule Florence (1804-1879). Ensaio histórico-litterario. São Paulo: Typographia Andrade, Mello \& Comp., 1900.

- A typographia e a lythographia no Brasil. Revista do Instituto Histórico e Geográfico de São Paulo, São Paulo, v. XIII, p. 3-39, 1908.

BONNET, Manuel; MARIGNIER, Jean-Louis. Niépce, correspondance et papiers. Saint-Loupde- Varennes: Maison Nicéphore Niépce, 2003.

BURGI, Sergio. Hercule Florence et la photographie au Brésil. In.: MUSÉE D'ORSAY. L'Empire brésilien et ses photographes, Collections de la Bibliothèque Nationale du Brésil et de l'Institut Moreira Salles. Paris: Musée D’Orsay, 2005.

DIENER, Pablo.; COSTA, Maria de Fátima (org.). Um Brasil para Martius. Rio de Janeiro: Fundação Miguel de Cervantes, 2012. 
CARELLI, Mario. A descoberta da Amazonia. Os diários do naturalista Hercules Florence. São Paulo: Editora Marca D’ Água, 1995.

CASAL, Manuel Aires de. Corografia Brazilica, ou relação bistorico-geografica do Reino do Brazil composta e dedicada a Sua Magestade Fidelissima por hum presbitero secular do Gram Priorado do Crato. Rio de Janeiro: Impressão Régia, 1817.

COSTA, Maria de Fátima. De Xarayes ao Pantanal: a cartografia de um mito geográfico. Revista do IEB, São Paulo, n. 45, p. 21-36, set. 2007.

CRISTÓVÃO, Fernando. Para uma teoria da literatura de viagens. In.: (coord.). Condicionantes culturais da literatura de viagens. Coimbra: Almedina/FCT; Lisboa: Centro de Literaturas de Expressão Portuguesa da Universidade de Lisboa, 2002.

FERREIRA, Dirceu Franco; CANTARINO, Nelson Mendes. Um humanista nos trópicos: a singular trajetória de Hercule Florence no Brasil. In: VIDAL, Laurent; LUCA, Tânia Regina de. Franceses no Brasil, séculos XIX e XX. São Paulo: EdUnesp, 2009.

FERREZ, Gilberto; NAEF, Weston. Pioneer Photographers of Brazil, 1840-1920. Nova York: The Center of Inter-American Relations, 1976.

FLORENCE, Hercule. Mémoire sur la possibilité de décrire les sons et les articulations de la voix des animaux. Rio de Janeiro: Tipografia R. Ogier, 1831.

Invenção da poligrafia por Hercules Florence. Santos: Typographia Commercial de G. Delius, 1858.

Voyage Fluvial du Tiété à l'Amazone, par les Provinces Brésiliennes de St. Paul, Matto-Grosso, et Gram-Pará. Revista da Sociedade Scientifica de São Paulo, São Paulo, v. 1, n. 1, 1904; n. 2, 1905; n. 3-4, 1906; v. 2, n.1-7, 9-12, 1907.

Voyage Fluvial du Tiété à l'Amazone, par les Provinces Brésiliennes de St. Paul, Matto-Grosso, et Gram-Pará. Monaco Revue, Monaco, v. 1, n. 7, 17 mars 1912.

Viagem fluvial do Tietê ao Amazonas, de 1825 a 1829. 2a ed. São Paulo: Melhoramentos, 1948.

Viagem fluvial do Tietê ao Amazonas pelas Províncias brasileiras de São Paulo, Mato Grosso e Grão-Pará (1825-1829). Tradução Francisco Álvares Machado e Vasconcellos Florence. São Paulo: Museu de Arte de São Paulo Assis Chateaubriand, 1977.

Mémoire sur la possibilité de décrire les sons et les articulations de la voix des animaux. In.: J. M. E. Vielliard (org.). A Zoophonia de Hercule Florence. Cuiabá: UFMT Editora Universitária, 1993. p. 19.

GONÇALVES, Sérgio Campos. A escrita da história do Brasil: o pensamento civilizador no Instituto Histórico e Geográfico Brasileiro. In: NICOLAZZI, Fernando; MOLLO, Helena; ARAUJO, Valdei (org.). Caderno de resumos $\varepsilon$ Anais do $4^{\circ}$ Seminário Nacional de História da Historiografia: tempo presente \& usos do passado. Ouro Preto: EdUFOP, 2010.

HALLEWELL, Laurence. O livro no Brasil: sua história. São Paulo: Edusp, 2005.

IVINS JR., William Mills. Prints and Visual Communication. 6. ed. Cambridge: The M.I.T. Press, 1985. 
KOMISSAROV, Boris. Expedição Langsdorff: acervo e fontes históricas. São Paulo: Editora Unesp; Brasília: Edições Langsdorff, 1994.

KOSSOY, Boris. A descoberta isolada da fotografia no Brasil. São Paulo: Edusp, 2006.

LISBOA, Karen Macknow. A nova Atlântida de Spix e Martius: natureza e civilização na viagem pelo Brasil (1817-1820). São Paulo: Hucitec/ FAPESP, 1997.

Mundo novo, mesmo mundo. Viajantes de língua alemã no Brasil (1893-1942). São Paulo: Hucitec/ Fapesp, 2011.

MCCAULEY, Anne. Writing Photography's History before Newhall. History of Photography, Londres, v. 21, n. 2, p. 87-101, 1997.

MONTEIRO, Rosana Horio. Descobertas múltiplas - a fotografia no Brasil (1824-1833). Campinas: FAPESP/ Mercado de Letras, 2001.

MÜLLER, Daniel Pedro. Ensaio d'um quadro estatistico da Provincia de São Paulo. Ordenado pelas Leis Provinciais de 11 de abril de 1836 e 10 de março de 1837. São Paulo: Tipografia de Costa Silveira, 1838.

NIÉPCE, Isidore. Historique de la découverte - improprement nommée Daguerréotype. Paris: Imprimerie de $\mathrm{M}^{\mathrm{me}} \mathrm{V}$ Dondey-Dupré; Astier Libraire, 1841.

PARRON, Tâmis Peixoto. A política da escravidão no Império do Brasil, 1826-1865. Rio de Janeiro: Civilização Brasileira, 2011.

SCHWARZ, Roberto. Um mestre na periferia do capitalismo: Machado de Assis. São Paulo: Duas Cidades/ Ed. 34, 2000.

TALBOT, William Henry Fox. The Pencil of Nature. Londres: Logman, Brown, Green and Longmans, 1844.

TAUNAY, Affonso d’Escragnole. A expedição do cônsul Langsdorff ao interior do Brasil. In: FLORENCE, Hercule. Viagem fluvial do Tietê ao Amazonas, de 1825 a 1829, $2^{\text {a }}$ ed. São Paulo: Melhoramentos, 1948.

Esboço da viagem do sr. Langsdorff no interior do Brasil pelo $2^{\circ}$ desenhista da comissão scientifica Hercules Florence. Revista Trimensal do Instituto Histórico, Geográphico e Ethnográfico do Brasil, t. 38, 1875.

TURAZZI, Maria Inez. O "homem de invenções" e as "recompensas nacionais". Notas sobre H. Florence e L.J.M. Daguerre. Anais do Museu Paulista, v. 16, n.2, p. 24, jul-dez. 2008.

VANZOLINI, Paulo E. A contribuição zoológica dos primeiros naturalistas viajantes no Brasil. Revista USP, São Paulo n. 30, p. 190-238, jun.-ago. 1996.

VASQUEZ, Pedro. K. O Brasil na fotografia oitocentista. São Paulo: Metalivros, 2003.

VIDAL, Laurent.; LUCA, Tânia Regina de. Franceses no Brasil, séculos XIX e XX. São Paulo: EdUnesp, 2009.

Artigo apresentado em 09/2014. Aprovado em 12/2014. 